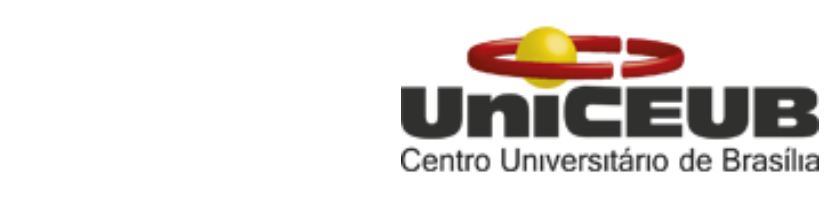

CENTRO UNIVERSITÁRIO DE BRASÍLIA - UnICEUB PROGRAMA DE INICIAÇÃO CIENTíFICA

RAQUEL OLIVEIRA DE ALBUQUERQUE

USOS DOS ESPAÇOS E MANUTENÇÃO DOS PARQUES DE MADRID

BRASÍLIA

2018 


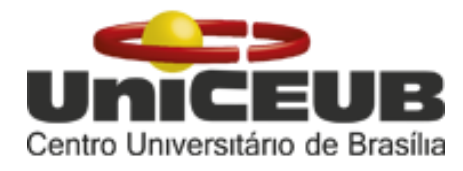

RAQUEL OLIVEIRA DE ALBUQUERQUE

\title{
USOS DOS ESPAÇOS E MANUTENÇÃO DOS PARQUES DE MADRID
}

\author{
Relatório final de pesquisa de Iniciação Científica \\ apresentado à Assessoria de Pós-Graduação e \\ Pesquisa.
}

Orientação: Prof. ${ }^{a}$ Dra. Eliete de Pinho Araujo

\section{BRASÍLIA}

2018 


\title{
PIC VOLUNTÁRIO ARQUITETURA E URBANISMO USOS DOS ESPAÇOS E MANUTENÇÃO DOS PARQUES DE MADRID
}

\author{
Raquel Oliveira de Albuquerque - UniCEUB, PIC voluntário em Arquitetura e \\ Urbanismo \\ raquel.albuquerque@sempreceub.com
}

\author{
Eliete de Pinho Araujo - UniCEUB, professor orientador \\ eliete.araujo@ceub.edu.br
}

Madrid é uma cidade conhecida pelos seus diversos parques, sejam eles grandes ou pequenos, criados em diferentes contextos e utilizados de acordo com a necessidade da população. Cada parque é singular, uma vez que buscam resolver a problemática de construir um espaço verde com diferentes tratamentos paisagísticos e de usos diversos, por isso, resolveu-se estudar como sucede o funcionamento desses parques. O objetivo da pesquisa é mostrar como é feita a manutenção de parques em diversas extensões, além de incentivar a prática de técnicas sustentáveis. Visa catalogar os usos e analisar a influência da tipologia de usos pelo público frequentador. A metodologia foi fazer a revisão bibliográfica e a seleção dos três parques para se desenvolver o estudo. O Parque El Retiro é o maior de Madrid sendo utilizado para lazer, entretenimento, atividades físicas e eventos culturais, que acontecem anualmente. É um parque que traz reconhecimento a todos os habitantes locais, além de atrair turistas do mundo inteiro. O Parque del Oeste também é um parque grande, reconhecido por ter uma diversidade de rosas devido a premiações em concursos internacionais. Já o Parque Dalieda San Francisco é bem menor e tem o seu uso contemplativo, sendo frequentado por moradores locais. Como resultados, a manutenção dos parques é feita pela prefeitura de Madrid, por empresas terceirizadas e nos parques menores esse cuidado é também feito voluntariamente por moradores locais. Cada parque é único em sua história e esta, muitas vezes, encontra-se marcada nos monumentos e estátuas dispostos ao longo deles. Apesar das diferenças, o que torna esses parques semelhantes é o conceito de que ambos seguem introduzidos no ambiente urbano, conectando diversos pontos da cidade.

Palavras-Chave: Parques. Infraestrutura. Uso. Manutenção. 


\section{LISTA DE FIGURAS}

Figura 01 - Zoneamento do Parque El Retiro

Figura 02 - Parterre

Figura 03 - Árvore podada

Figura 04 - Grande Lagoa

Figura 05 - Quiosque de Música

Figura 06 - Colina Artificial

Figura 07 - Casita del Pescador

Figura 08 - Calçadas e pérgolas

Figura 09 - Zona Canina

Figura 10 - Observatório Astronômico

Figura 11 - Noria de la Fábrica de Porcelana

Figura 12 - Centro Deportivo Municipal la Chopera

Figura 13 - Palácio de Cristal recém construido.

Figura 14 - Plantas exóticas.

Figura 15 - Palácio de Cristal.

Figura 16 - Rampa de Acesso ao Palácio de Cristal.

Figura 17 - Lago situado em frente ao Palácio de Cristal.

Figura 18 - Fachada do Palácio de Velazquez.

Figura 19 - O Estanque.

Figura 20 - O Estanque e estátuas.

Figura 21 - Monumento Afonso XII

Figura 22 - Pessoas ao redor da banda.

Figura 23 - Biblioteca.

Figura 24 - El Paseo de Coches.

Figura 25 - Fonte Egípcia.

Figura 26 - Porta da Independência.

Figura 27 - Fonte da Independência.

Figura 28 - O Anjo Caído

Figura 29 - Feira do Livro.

Figura 30 - La Rosaleda.

Figura 31 - Trabalhador cortando a grama

Figura 32 - Trabalhador varrendo o chão. 
Figura 33 - Veículo.

Figura 34 - Imagem gerada pelo georadar.

Figura 35 - Mapa do Parque del Oeste.

Figura 36 - Zoneamento da Rosaleda.

Figura 37 - La Rosaleda.

Figura 38 - La Rosaleda

Figura 39 - Templo de Debod

Figura 40 - Teleférico.

Figura 41 - Escuela de arte Francisco Alcántara.

Figura 42 - Monumento a Goya.

Figura 43 - Monumento Sor Juana Inés de la Cruz a Madrid.

Figura 44 - Vista do Mirante para o Templo de Debod

Figura 45 - Vista do Mirante para a cidade

Figura 46 - Fonte de Juan de Villanueva

Figura 47 - Estátua Eduardo Rosales.

Figura 48 - Monumento a Cervantes

Figura 49 - Observatório de pássaros

Figura 50 - Ninho artificial.

Figura 51 - Mapa do Parque Dalieda de San Francisco.

Figura 52 - Canteiro de Dálias

Figura 53 - Espaço verde temático.

Figura 54 - Escultura El sueño de San Isidro.

Figura 55 - Canteiro de Dálias com vista para a Igreja de São Francisco.

Figura 56 - Manutenção do canteiro de Dálias.

Figura 57 - Mapa do Parque El Retiro com os usos em destaque.

Figura 58 - Mapa do Parque del Oeste com os usos em destaque.

Figura 59 - Mapa do Parque Dalieda de San Francisco com os usos em destaque.

Figura 60 - Mapa de Madrid com a locação dos três parques. 


\section{LISTA DE TABELAS}

Tabela 01 - Usos do El Retiro.

Tabela 02 - Usos do Parque del Oeste.

Tabela 03 - Usos do Parque Dalieda de San Francisco. 
1. INTRODUÇÃO

2. OBJETIVOS 8

3. JUSTIFICATIVA 9

4. REVISÃO BIBLIOGRÁFICA/REFERENCIAL TEÓRICO 10

4.1. Contexto histórico 10

4.2. A importância do espaço verde na cidade 11

4.3. Usos dos espaços verdes públicos 12

4.4. Manutenção dos espaços verdes públicos 13

4.5. Critérios utilizados para projetar um parque urbano 14

5. METODOLOGIA 16

6. PARQUE EL RETIRO 17

6.1. História 17

6.2. Usos 22

6.3. Manutenção 32

7. PARQUE DEL OESTE 34

7.1. História 34

7.2. Usos 35

7.3. Manutenção 46

8. PARQUE DALIEDA DE SAN FRANCISCO 47

8.1. História 47

8.2. Usos 48

8.3. Manutenção 50

9. RESULTADOS E DISCUSSÕES

10. CONSIDERAÇÕES FINAIS 55

11. REFERÊNCIAS BIBLIOGRÁFICAS 56 


\section{INTRODUÇÃO}

O ajardinamento das cidades é uma preocupação presente desde o século XIX com o intuito de solucionar questões sustentáveis e proporcionar ao homem espaços de lazer. A partir do século XIX, vê-se a importância do planejamento e da administração desses espaços com o objetivo de atender a população. Atualmente os espaços verdes assumem papel fundamental na cidade, ao admitir usos coletivos disponíveis a todos os cidadãos, bem como a conservação fundamentada na autossuficiência e na reutilização de recursos naturais.

Os espaços verdes contribuem para melhorar os condicionantes ambientais da cidade, além de promover caráter de igualdade socioeconômica entre os usuários e favorecer uma relação intergeracional. Em vista disto, a existência de parques urbanos se tornou um dos elementos básicos que definem a qualidade de vida em uma cidade. A participação dos cidadãos é um elemento indispensável tanto para dar utilidade e vida, quanto para uma boa manutenção dos espaços verdes.

Os parques estudados estão situados na cidade de Madrid, Espanha, sendo todos relevantes no panorama histórico da cidade e na cultura popular. Além do reconhecimento e importância dada pelos habitantes locais aos parques, estes atraem turistas do mundo inteiro. Cada parque é singular, uma vez que buscam resolver a problemática de construir um espaço verde com diferentes tratamentos paisagísticos e de usos diversos, por isso, resolveu-se estudar como sucede o funcionamento desses parques.

\section{OBJETIVOS}

\section{Geral:}

Estudar os usos dos parques urbanos e sua manutenção na cidade de Madrid Específicos:

- Entender as técnicas de conservação e administração dos parques;

- Estudar tecnologias utilizadas atualmente no campo da manutenção dos parques;

- Estudar as possibilidades e combinações de usos em um parque.

- Categorizar os usos dos parques;

- Incentivar os profissionais da área sobre a utilizar espécies nativas do 
local;

- Estimular a coleta e o reaproveitamento de água nos parques;

- Mostrar que é possível projetar parques de modo que não consuma muita água e que não sobrecarregue o governo economicamente, e que beneficie a população;

- Demonstrar como a qualidade de vida está diretamente ligada às questões ambientais e sociais do indivíduo;

- Explanar diretrizes básicas quanto à elaboração dos projetos e ocupação de áreas verdes públicas;

- Exemplificar em nível de projeto a estrutura de um parque urbano e seu mobiliário.

\section{JUSTIFICATIVA}

O processo de projetar um parque urbano expandiu-se do âmbito ecológico e, atualmente, as questões sociais são abordadas com bastante relevância, isso porque os parques são espaços distintos e memoráveis na cidade, além de trazerem qualidade de vida para as pessoas. Devido a mudanças na população e na participação da comunidade, os usos assumem múltiplas funções, a fim de incorporar a diversidade de práticas culturais em parques públicos. Esses fatores acarretam em mudanças no sítio que afetam não apenas sua organização, mas também a experiência que oferece a seus usuários. Ao mesmo tempo em que parques proporcionam lazer, eles também representam enormes desafios. Eles são caros para projetar e construir, bem como para gerenciar e manter. Ao elidir a manutenção de um parque, ele pode rapidamente entrar em estado de abandono.

Posto isso, é fundamental entender o funcionamento dos parques em relação aos usos e funções, bem como a conservação e administração. Assim, o estudo de caso dos parques de Madrid é conveniente para entender conceitos abordados em cada parque, além de apresentar soluções adotadas quanto aos usos e manutenção no contexto da cidade. Os parques, afinal, não são simplesmente espaços naturais encontrados em um sítio, eles são projetados, construídos e administrados conforme as peculiaridades do local, a fim de que as pessoas Ihes usufruam da melhor forma possível. 


\section{REVISÃO BIBLIOGRÁFICA/REFERENCIAL TEÓRICO}

\subsection{Contexto Histórico}

A paisagem rural é vista esteticamente desde a Antiguidade com os palmeirais, vinhedos e olivais estabelecidos do Ocidente, bem como os arrozais irrigados do Oriente. Eles são relevantes não apenas porque as plantações bem traçadas aumentam a produtividade, mas também porque revelam um senso de beleza intrínseca (PANZINI, 2013). Durante toda a história é possível salientar a relação do homem com a natureza.

Segundo Panzini (2013), as cavernas-santuário, pedras cravadas e montanhas artificiais constituem os primeiros componentes do desenho da paisagem. Essas intervenções pretendiam associar o homem e o trabalho à natureza, com isso se desenvolveu a agricultura e o sedentarismo dos grupos humanos. A evolução da agricultura ocorreu concomitantemente ao aparecimento de técnicas para expandir o terreno cultivável. Por volta de 4000 a.C., no sul da Mesopotâmia, técnicas simples de irrigação em pequena escala foram desenvolvidas e com o uso de tecnologias, chegou-se à criação de redes de irrigação. Durante o segundo milênio foram registradas zonas verdes arborizadas em residências reais, não somente com função utilitária, mas também com finalidade de repouso, lazer e socialização. Já no Egito, graças ao Rio Nilo, o solo era fértil e possibilitou a plantação de árvores frutíferas e de hortaliças. A Roma Imperial (27 a.C. a 286 d.C.) é marcada por um cinturão verde em torno do centro urbano devido ao desenvolvimento da arquitetura e o crescimento da cidade.

Durante o Período Medieval (séculos $\mathrm{V}$ a XV) as cidades eram pequenas e os principais espaços públicos eram os mercados e as ruas, mas no final do século XVIII um novo fator foi introduzido: a criação de zonas verdes com o intuito de promover um espaço para as pessoas desfrutarem nos tempos de ócio. O ajardinamento das cidades no século XIX procurou atender critérios higienistas e recreativos, assim, foram incorporados espaços abertos a fim de aumentar a qualidade do ar na cidade, além de contemplar aspectos sociais, como a necessidade de espaços para aqueles que tinham longas jornadas de trabalho. (FALCÓN, 2007). 
Hoje os espaços verdes assumem papel fundamental na cidade, com critérios de uso coletivo ao serviço de todos os cidadãos, bem como a conservação fundamentada na auto suficiência e na reutilização de recursos naturais. Há grande relevância dos espaços verdes no campo de estudo, como a UNESCO, por meio do programa El Hombre y la Biosfera, dedicado aos aspectos ecológicos dos sistemas urbanos, ao considerar os espaços verdes como elementos fundamentais no equilíbrio ecológico das cidades. (FALCÓN, 2007).

\subsection{A importância do espaço verde na cidade}

Com o crescimento da população em áreas urbanas verifica-se a importância do espaço verde nas cidades e a necessidade de planejar o seu crescimento. Por exemplo, os habitantes de pequenas cidades, que se fundamentam na agricultura, rodeado de campos e bosques, têm em abundância o que é escasso em cidades grandes. Quanto maior a população urbana maiores serão os problemas urbanísticos para criar os espaços verdes necessários e administrá-los. (FALCÓN, 2007).

Os parques são áreas verdes que fazem conexão com a cidade. Além de seus efeitos culturais, eles também são valorizados por suas funções ecológicas. As vastas extensões de terra são eficazes para drenagem de águas pluviais, para resfriar a temperatura do ar no núcleo urbano e para fornecer habitat a uma rica vida vegetal, animal, aquática e microbiana (CORNER in Large Parks, 2007).

Além de meramente ornamental, os espaços verdes assumem usos diversos, eles proporcionam o contato com a natureza, promovendo desde o descanso das pessoas, até a prática de atividades lúdicas e educação ambiental. Também cumprem uma função bastante relevante: estabelecem caráter de igualdade social e econômica entre os seus usuários com a possibilidade de atender a população mais carente, além de favorecer uma relação intergeracional ao situar atividades distintas que abrangem diversas faixas etárias em um mesmo local (FALCÓN, 2007).

Os parques são fundamentais para as cidades, não apenas porque assumem funções ecológicas nos centros urbanos, mas também porque são lugares distintos e memoráveis. Absorvem a identidade da cidade tanto quanto a projetam, tornando- 
se lugares socialmente e culturalmente reconhecidos. (BERRIZBEITIA in Large Parks, 2007).

\subsection{Usos dos espaços verdes públicos}

Os parques urbanos são locais que precisam de vida e somente as pessoas, que dão utilidade aos parques e fazem deles um sucesso, ou então não o usam e os condenam ao fracasso. O entendimento dos parques é complexo, pois são locais efêmeros podendo experimentar tanto popularidade quanto impopularidade. Nos parques de pouco uso seus equipamentos são alvos de vandalismo, pois, um parque é diretamente afetado pela maneira como as pessoas nele interferem. (JACOBS, 2011)

A variedade de usos dos edifícios no entorno propicia ao parque uma variedade de usuários que nele entram e dele saem em horários diferentes porque os compromissos diários das pessoas são diferentes. Os parques ajudam na articulação entre as atividades vizinhas, que propiciam locais agradáveis, somam a diversidade e prestam serviço ao entorno. (JACOBS, 2011)

Grandes parques tornam-se lugares significativos tanto por suas qualidades físicas quanto pelos eventos que ocorrem dentro deles. Alguns eventos são efêmeros e tem a intenção de desaparecer, outros são intervenções permanentes no sítio. (BERRIZBEITIA in Large Parks, 2007) A complexidade diz respeito à multiplicidade de motivos que as pessoas têm para frequentar o parque. Uma pessoa vai ao parque por motivos diferentes e em horários diferentes. Às vezes para descansar, para jogar ou assistir a um jogo, para ler ou trabalhar, para encontrar com uma pessoa, para ter um pouco de contato com a natureza, para manter uma criança ocupada, ou só para se entreter com a presença de outras pessoas. (JACOBS, 2011)

A vista magnífica e paisagismo bonito não funcionam como artigo de primeira necessidade, ele funciona apenas como complemento. Já as quadras de esportes, festas ou atividades que tenham caráter funcionam como artigo de primeira necessidade. (JACOBS, 2011). Os equipamentos e o mobiliário urbano determinam em grande parte os usos de um espaço verde, por isso é importante que a sua escolha seja feita com base nas necessidades do seu entorno. As razões pelas 
quais um cidadão permanece em uma área verde são diversas, mas as principais são: lúdicas e recreativas, culturais, esportivas, contemplativas ou atividades participativas. Um espaço de qualidade deve potencializar usos diferenciados, pois a diversidade de usos em um mesmo espaço é a base de um espaço de convivência de qualidade. (FALCÓN, 2007).

É indispensável analisar as necessidades do entorno a quem o espaço será destinado. Deve ser estudada a sua zona de influência e sua população, isso permitirá definir as expectativas e demandas daquele local. Todos esses dados contribuem para criar um espaço verde de qualidade, que em muitos aspectos sua função dependerá de sua localização (FALCÓN, 2007).

Os usos de um parque alteram devido às mudanças na população, na participação da comunidade e na incorporação de uma diversidade cada vez maior de práticas culturais em paisagens públicas. Tudo isso traz mudanças em um parque que, afetam não apenas sua organização, mas também a experiência que oferece a seus usuários. (BERRIZBEITIA in Large Parks, 2007). Os parques são um atrativo a mais nas cidades, mas nada significa se seus usos forem ignorados. Quanto mais a cidade conseguir mesclar a diversidade de usos e usuários, mais a população conseguirá sustentar os parques com sucesso. (JACOBS, 2011)

\subsection{Manutenção dos espaços verdes públicos.}

Ao mesmo tempo em que parques proporcionam lazer, eles também representam enormes desafios, pois são caros para projetar e construir e, mais caros ainda ao longo do tempo para gerenciar e manter. Ao eliminar a manutenção de um parque, ele pode rapidamente entrar em estado de abandono (CORNER in Large Parks, 2007). Quando isso acontece, os parques se tornam local de uso ilícito e de violência, por isso que a participação dos cidadãos é um elemento indispensável para uma boa manutenção dos espaços verdes. (FALCÓN, 2007). Os parques, afinal, não são simplesmente lugares naturais ou encontrados, são construídos e projetados.

Uma das principais escolhas das plantas que participarão da composição do espaço é o seu consumo de água, visto que ela é essencial para o desenvolvimento e manutenção dos parques e praças. O controle do consumo de água deve levar em 
consideração o total de área verde, a superfície cultivada, pluviometria média e o consumo de água do solo e de árvores. Esse levantamento é essencial para a manutenção, uma vez que em alguns casos necessitam de irrigação superficial (FALCÓN, 2007).

A drenagem e a evacuação de águas são importantes, posto que um mau planejamento nessa área possa acarretar em alagamentos. Uma solução para esse problema tão comum em diversos locais seria a reutilização dessa água para o consumo do próprio parque, como irrigação, limpeza e cultivo (FALCÓN, 2007).

\subsection{Critérios utilizados para projetar um parque urbano.}

Dois aspectos principais devem ser levados em consideração ao se pensar em um espaço verde: que ele tenha benefício social e ambiental e que as necessidades de recursos (econômicos, materiais e naturais) sejam mínimas. Esse segundo aspecto pode ser resolvido ao utilizar um planejamento sustentável fundamentado na escolha de espécies vegetais que precisam de pouca manutenção, assim como na escolha dos elementos construtivos e do mobiliário urbano (FALCÓN, 2007). Portanto, a estrutura de um parque é baseada no conjunto de três aspectos: o ecológico, o social e o econômico, juntos eles oferecem oportunidades de sustentabilidade, gerenciamento, planejamento e manutenção de parques (LISTER in Large Parks, 2007).

Muitos parques de sucesso compartilham duas características essenciais: legibilidade e resiliência. Isto é, eles devem ser compreendidos em suas intenções (objetivo), identidade (caráter) e imagem (aparência), mas também devem ser capazes de se adaptar diante de mudanças regulares (CZERNIAK in Large Parks, 2007). Desde sua concepção, o projeto do espaço deve preservar os recursos naturais, intensificar a biodiversidade, o seu uso social e permitir uma gestão e manutenção equilibrada. Esses critérios devem estar presentes desde o início do projeto, ao determinar as espécies vegetativas, ao proporcionar acessibilidade para todos, na construção de obras de infraestrutura e na escolha de um mobiliário que seja ecologicamente eficiente (FALCÓN, 2007).

O clima exerce papel primordial sobre o espaço verde, pois pelos vários tipos de climas existentes é possível compreender quais tipos de fauna e flora existem no 
local, por isso, no projeto paisagístico esse elemento deve ser considerado. Cada clima fará com que espécies nativas ou outras espécies que consigam se adequar ao local (FALCÓN, 2007).

O mobiliário urbano é semelhantemente importante, pois deve levar em consideração os aspectos de sustentabilidade e durabilidade do material, visto que esse mobiliário estará sujeito à intempéries. O mobiliário urbano, assim como todo o conjunto do parque deve atender a normas mínimas, tais como ser acessível a todos, para que dessa forma esse espaço público tenha as referências necessárias de um ambiente completo (FALCÓN, 2007). 


\section{METODOLOGIA}

A pesquisa aplica-se ao tema de parques urbanos e sua abordagem é qualitativa ao interpretar os resultados dos estudos obtidos por meio de análises e buscar a compreensão destes. Teve fundamentação teórica e estudo de caso. Os locais escolhidos para o levantamento de dados foram: Parque El Retiro, Parque Del Oeste e Dalieda San Fancisco, situados em Madrid, Espanha. Esses locais foram selecionados devido à sua importância e significado cultural para a cidade, por possuírem características que diferem entre si, além de apresentarem soluções válidas para a utilização e manutenção de parques urbanos em um contexto mais amplo.

A pesquisa levantada na revisão bibliográfica referente ao tema abordou a origem dos parques na cidade e da necessidade do homem por espaços verdes, além de mudanças na arquitetura da paisagem segundo Panzini (2013), bem como a importância de um parque no meio urbano, os critérios utilizados ao se projetar um parque, além dos usos que um parque pode ter e como se dá a manutenção desses espaços segundo Falcón (2007) e demais autores que abordam o tema.

Com base na revisão bibliográfica foram selecionados três parques para o desenvolvimento do estudo. Foram levantados os seguintes dados de cada parque: a história, o uso e a manutenção. A partir desses dados foi feito o diagnóstico das áreas. Foram analisados os mapas dos três parques urbanos de acordo com o seu uso. Por fim, foi discutido como os usos de um parque interferem em sua manutenção e consequentemente definem a qualidade desse espaço. 


\section{PARQUE EL RETIRO}

\subsection{História}

O Parque Retiro tem grande relevância no panorama de Madrid desde suas origens até os dias atuais e tem sido destaque em muitos altos e baixos históricos a qual a cidade tem percorrido. Embora hoje já não tenha papel na história nem na política, o Parque Retiro não deixou de ser significativo, muito pelo contrário, tornouse protagonista da cultura popular dos habitantes. O Parque Retiro traz reconhecimento a todos os habitantes locais, pois cumpre a função mais importante que um parque pode ter: um lugar de encontro; o encontro entre vizinhos, com a natureza e com a cultura.

Sua existência deve-se ao palácio de Buen Retiro, conjunto de edifícios e jardins criados no século XVII, idealizado pelo conde-duque de Olivares para a corte de Felipe IV. Foi pensado em um lugar de descanso fora da cidade em que o rei poderia atuar como um grande protetor dos artistas, pois naquela época o patrocínio artístico consistia na maior manifestação da glória e riqueza. Através desse patrocínio viveram e trabalharam os melhores artistas da época: escritores, pintores, arquitetos, escultores, cenográficos, jardineiros, etc. Eles foram responsáveis pelo esplendor da cultura e das artes alcançaram nos últimos anos na Espanha.

Com o conjunto de pinturas armazenadas no palácio começaram a formar uma das galerias de arte mais importantes que existem hoje no mundo: o Museo del Prado. Ao redor do palácio foi criado um complexo jardim por justaposição de várias hortas jardineiras sem a existência de um projeto paisagístico prévio.

Devem-se considerar várias zonas do Parque Retiro (Figura 01). Em cada uma destas zonas o parque oferece uma concepção distinta de jardim, com uma ordenação específica de seus elementos, tantos botânicos, como estruturais. 


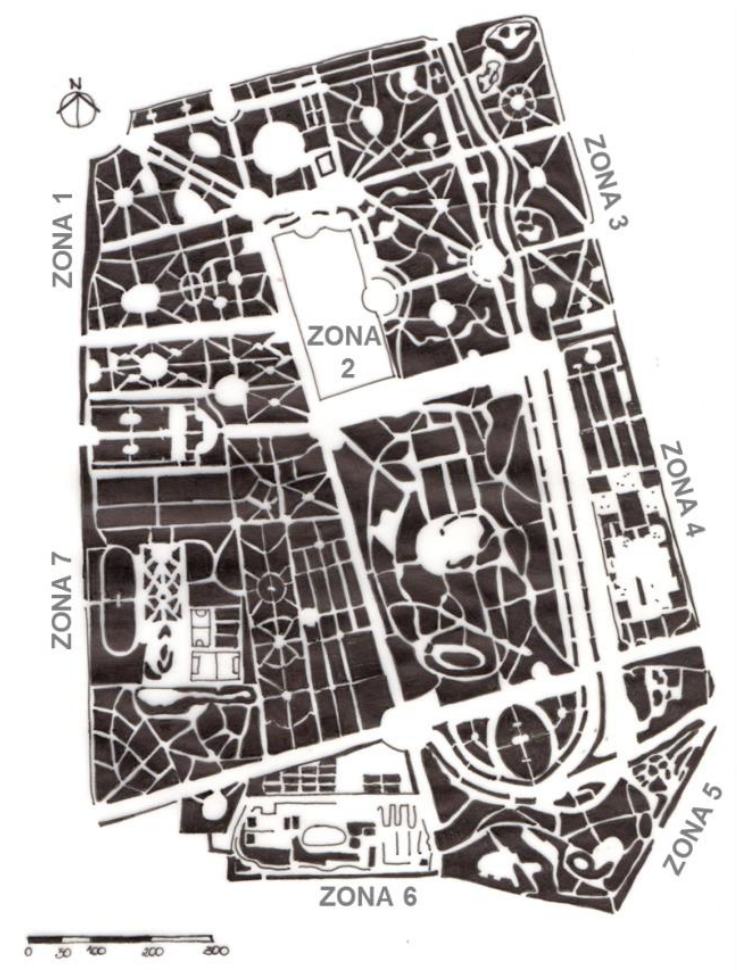

Figura 11 - Zoneamento do parque El Retiro. Fonte: Arquivo pessoal.

\section{1aㅡ zona - Parterre}

Representa a área de acesso principal para o parque. A partir da porta de Felipe IV, dois grandes passeios atravessam essa zona. Consiste em um jardim de estilo francês muito representativo. Existe também nesta zona outra porta que se abre para um jardim de fontes. O resto da zona tem um traçado clássico, mas foi reformado nos últimos anos (Figuras 02 e 03).
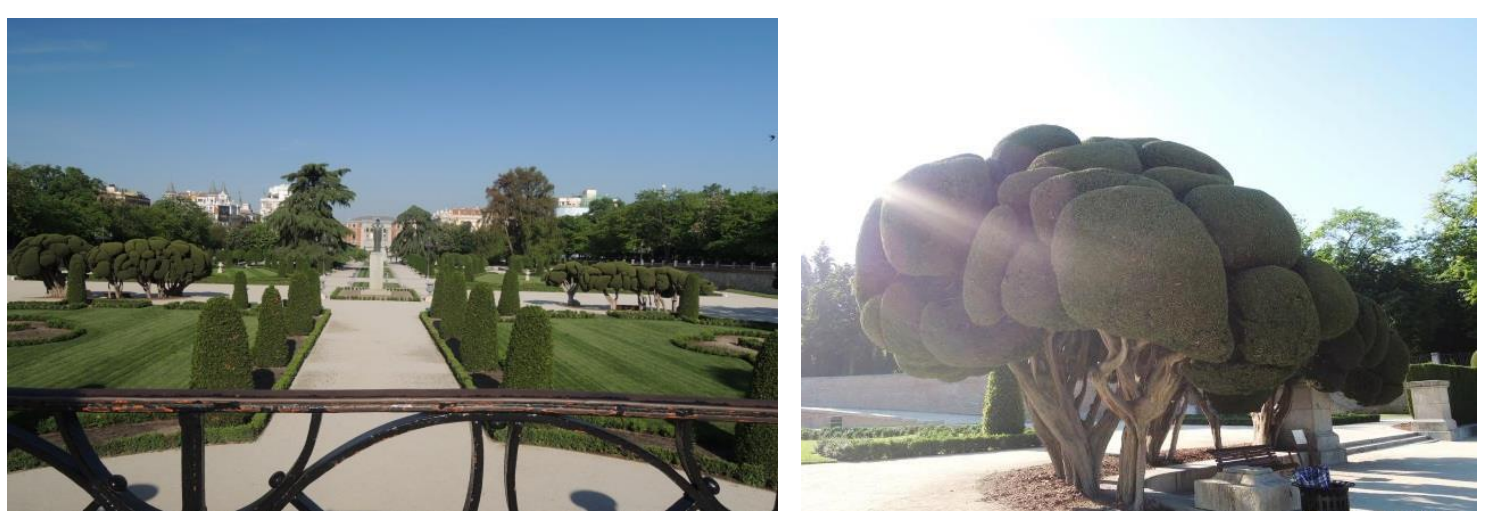

Figura 02 - Parterre. Fonte: Arquivo Pessoal

Figura 03 - Árvore podada. Fonte: Arquivo Pessoal 


\section{2aㅡ zona - Estanque}

É a zona central do parque e que concentra os lugares mais representativos do mesmo, como a Grande Lagoa (Figura 04), o Quiosque de Música (Figura 05), o monumento a Afonso XII, os palácios de Valazequiz e de Cristal (ambos convertidos em duas salas de exposição), o lago do Palácio de Cristal e diversas fontes e outros monumentos. É uma zona que tem sido muito modificada com o passar do tempo. $O$ traçado atual é moderno com um tratamento paisagístico de tipo inglês.

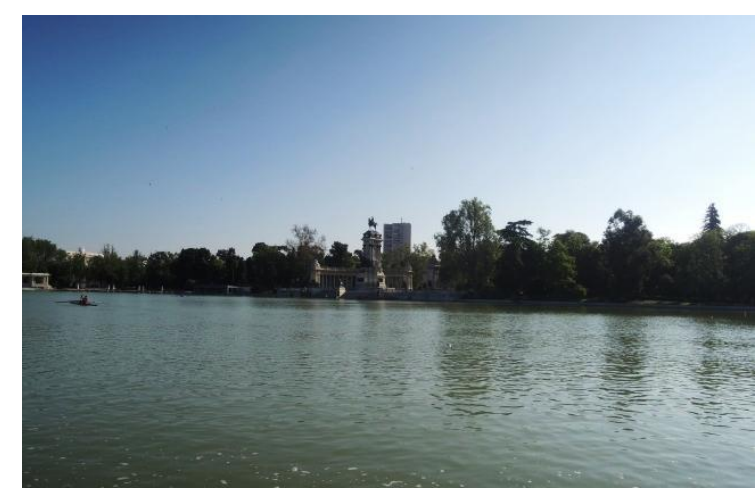

Figura 04 - Grande Lagoa

Fonte: Arquivo Pessoal

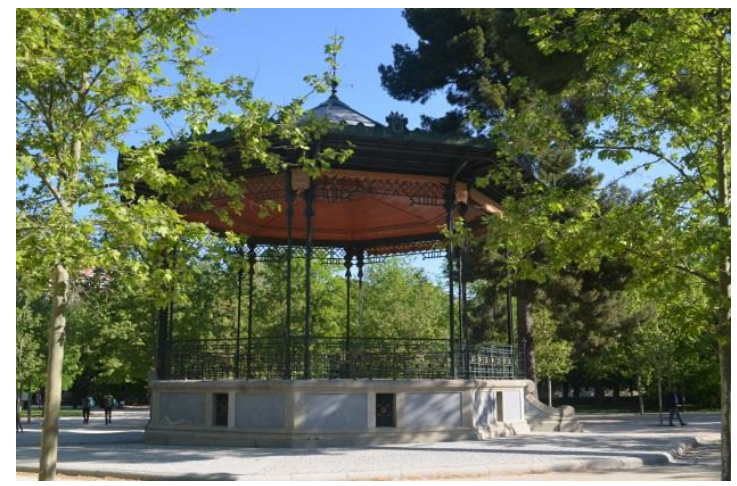

Figura 05 - Quiosque de Música

Fonte: Arquivo Pessoal

\section{3르 zona - Monte de los Gatos}

O que mais representa essa área, é a Colina Artificial com sua cascata (Figura 06), a Casita del Pescador (Figura 07) com o seu lago circundante, as ruínas da capela românica de San Isidoro e a Plaza del Mármol. Conserva-se parte do traçado clássico do jardim.

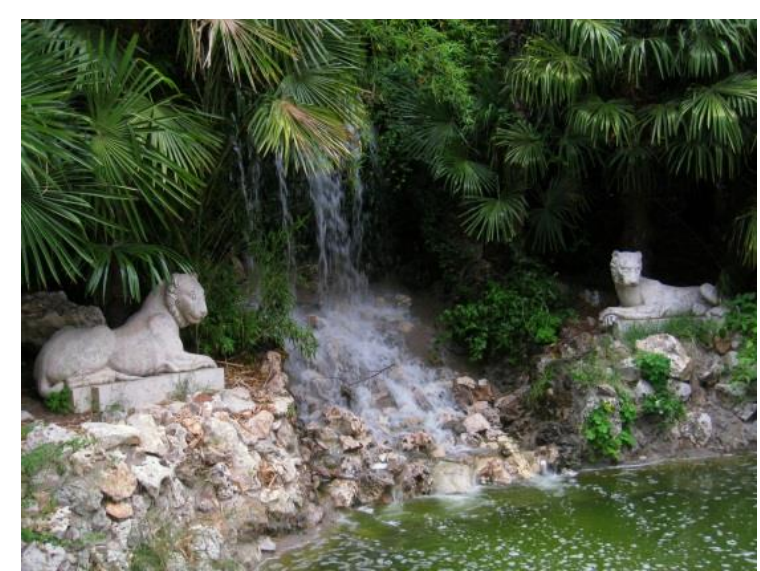

Figura 06 - Colina Artificial

Fonte: https://goo.gl/y4jWSr, acesso em 19 de agosto de 2017.

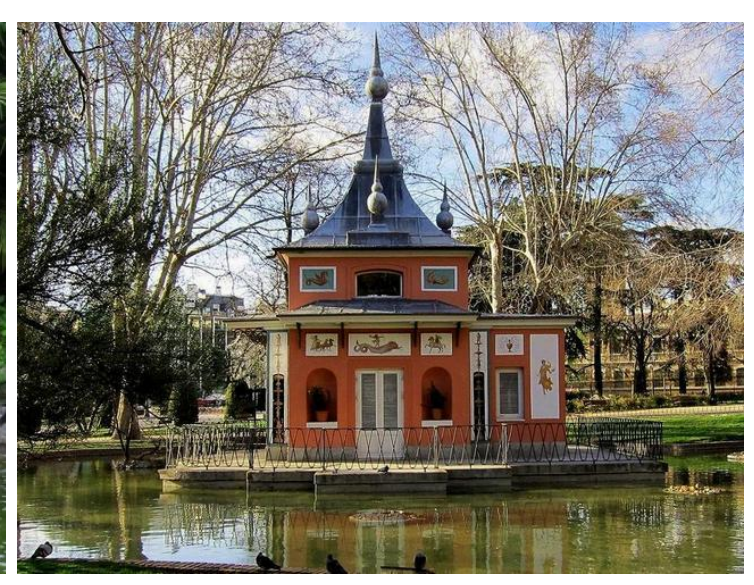

Figura 07 - Casita del Pescador

Fonte: https://goo.gl/bHy59g, acesso em 19 de agosto de 2017. 
4르 zona - Jardines de Don Cecilio

É a área onde abundam as flores sazonais. Seu desenho tem duas partes: uma clássica com calçadas e pérgolas (Figura 8) e a mais moderna com áreas irregulares, onde foi localizado o zoológico. Há um pavilhão onde são oferecidas ocasionalmente recepções. Ao longo do Paseo de Coches é tradicionalmente celebrada na primavera a Feira do Livro.

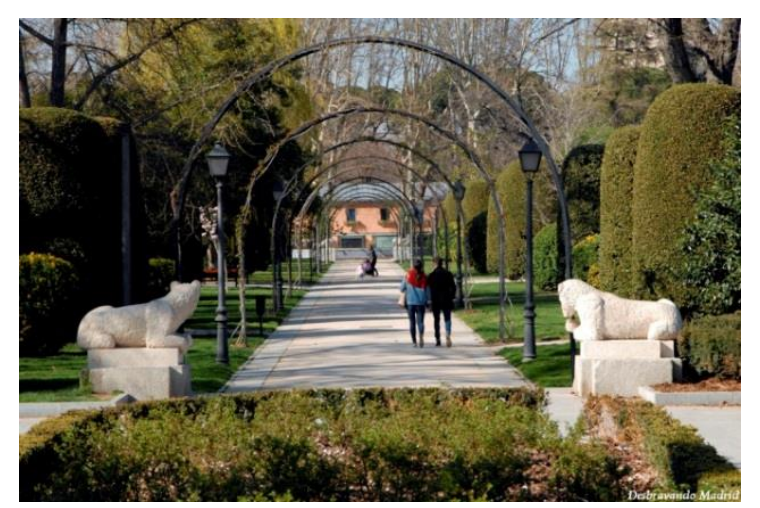

Figura 8 - Calçadas e pérgolas. Fonte: https://goo.gl/qB1UFy, acesso em 19 de agosto de 2017.

\section{5azona - Rocalla}

Era um dos cantos mais abandonados até alguns anos atrás, quando um jardim ornamental foi criado, incluindo uma variedade de espécies de plantas. Hoje há uma zona canina nessa área (Figura 9).

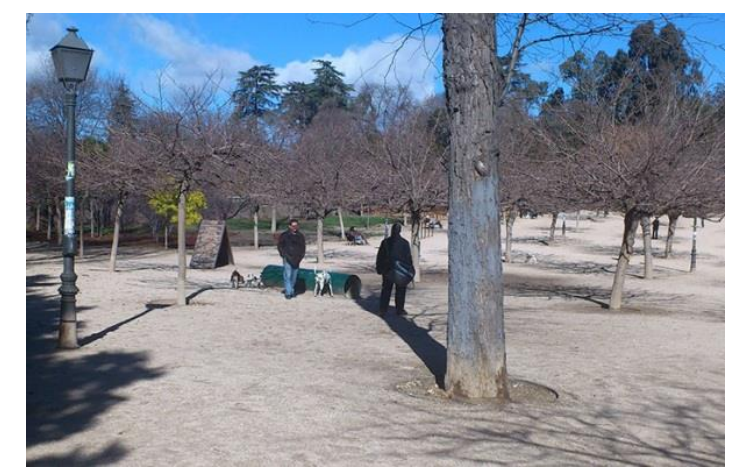

Figura 9 - Zona Canina. Fonte: https://goo.gl/c8Fm58, acesso em 20 de agosto de 2017.

\section{6ª zona - Astronómico}

Dentro da área estão localizados dois observatórios astronômicos (Figura 10). Foi construído recentemente um viveiro municipal com plantas sazonais e o Huerto del Francés, onde foi compilado um conjunto de pedras de monumentos desaparecidos (Figura 11). 


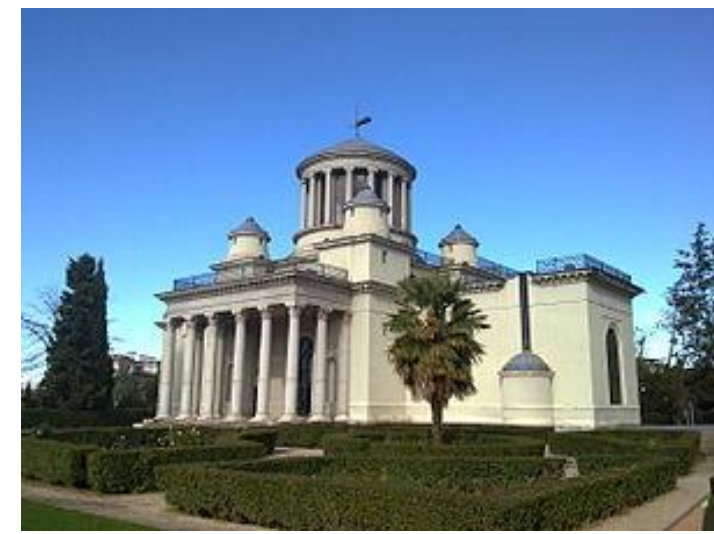

Figura 10 - Observatório Astronômico Fonte: https://goo.gl/qdJb1D, acesso em 19 de agosto de 2017.

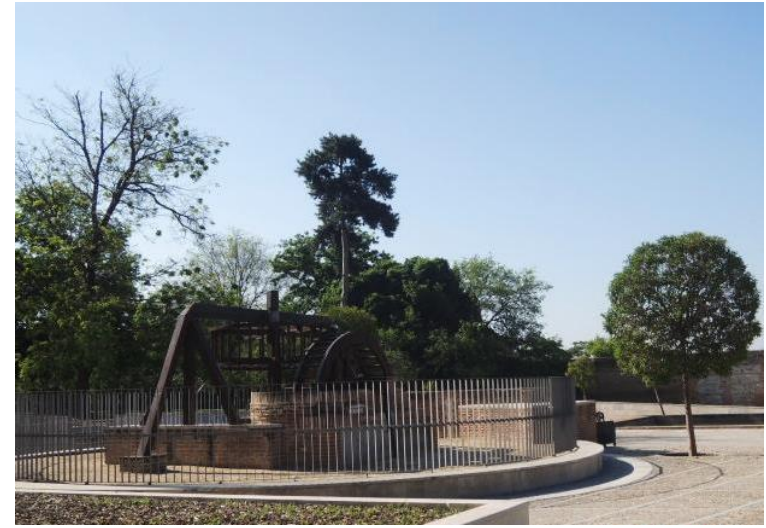

Figura 11 - Noria de la Fábrica de Porcelana Fonte: Arquivo Pessoal

\section{$7^{a}$ zona - la Chopera}

Dentro dessa área há um grande espaço livre, com muitas funções que vão desde um velódromo de bicicleta até instalações para festas populares, teatro ao ar livre e competições equestres. Anexado a este espaço aberto há instalações desportivas. Por isso é uma área de grande tradição popular (Figura 12).

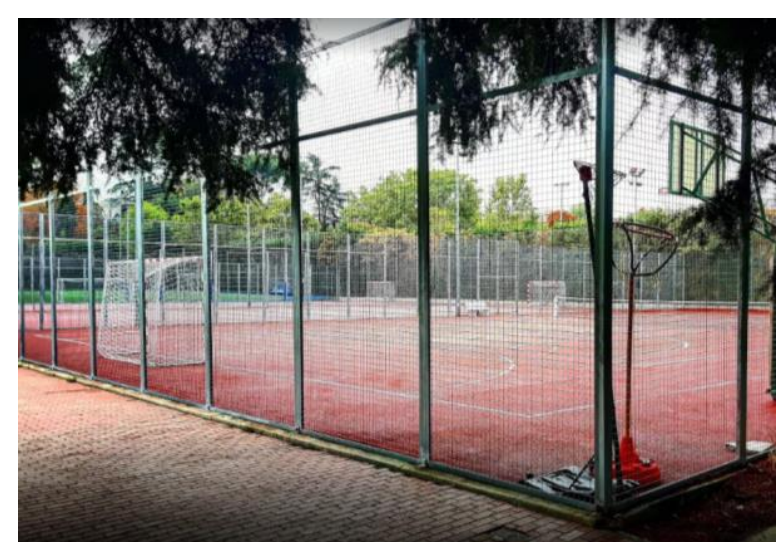

Figura 12 - Centro Deportivo Municipal la Chopera. Fonte: https://goo.gl/Z9cZEg, acesso em 19 de agosto de 2017. 


\subsection{Usos}

\section{Palácio de Cristal}

Construído em ferro fundido e vidro, o Palácio de Cristal foi erguido para abrigar a Grande Exposição de 1851. Projetado por Joseph Paxton, o edifício contava com um pé direito de 33 metros e tinha 564 metros de comprimento. Nele foram mostrados exemplos das últimas tecnologias desenvolvidas na Revolução Industrial, de modo a acolher mais de 14 mil expositores vindos de todo o mundo nos 92 mil metros quadrados de espaço de exibição. Após a exposição, o palácio foi desmontado e, em 1886, o palácio foi restaurado e conservado tal como foi idealizado, porém perdeu alguns de seus elementos como a "Puente de Cañas". Baseando-se no projeto de Paxton, o edifício foi reprojetado, pelo arquiteto Ricardo Valazquez Bosco, a fim de servir como estufa para a exposição de Filipinas de 1887 (Figuras 13 e 14).

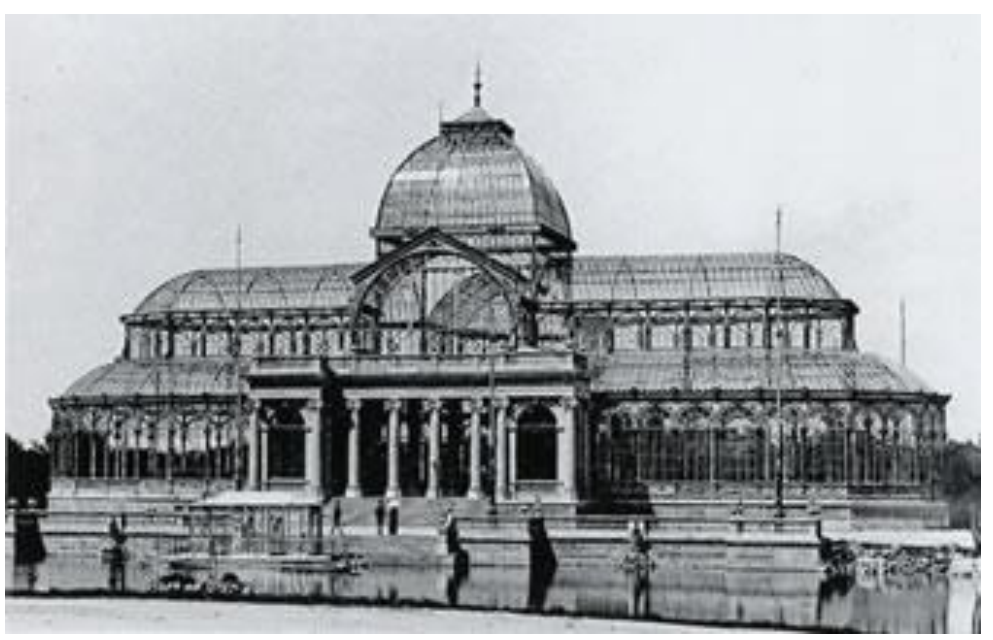

Figura 13 - Palácio de Cristal recém construido.

Fonte: https://goo.gl/bvD9r3, acesso em 25 de agosto de 2017

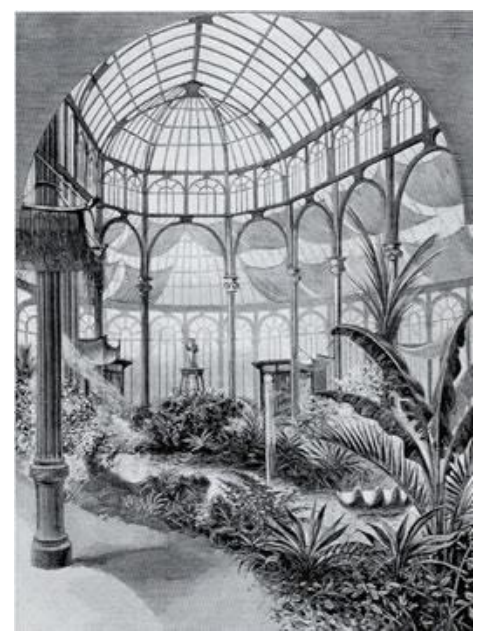

Figura 14 - Plantas exóticas. Fonte: https://goo.gl/bvD9r3, acesso em 25 de agosto de2017

Hoje é possível desfrutar deste local como sala de exposição de arte contemporânea, pertencente ao museu Reina Sofia (Figuras 15 e 16). Nos arredores do palácio há um lago com peixes, patos, cisnes e árvores ciprestes (Figura 17). As escadas funcionam como local para sentar, relaxar e aproveitar a vista do parque ao som de músicos, que algumas vezes vão ao parque para divulgar o seu trabalho. $O$ Palácio de Cristal e seus arredores são um dos lugares mais visitados e conhecidos no Parque Retiro. 


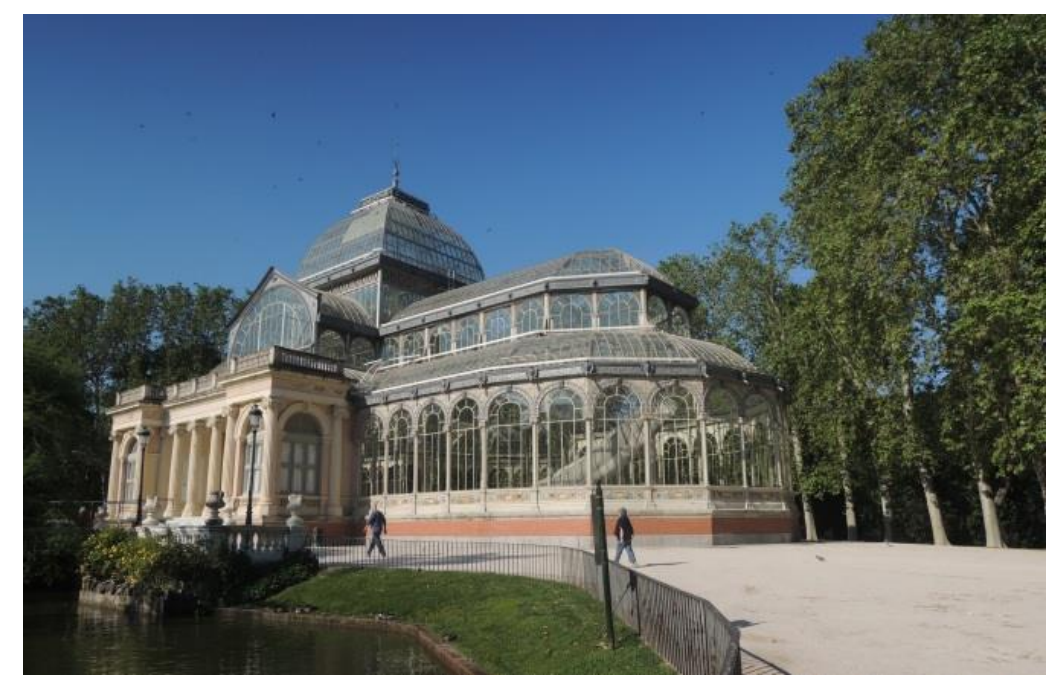

Figura 15 - Palácio de Cristal. Fonte: Arquivo Pessoal.

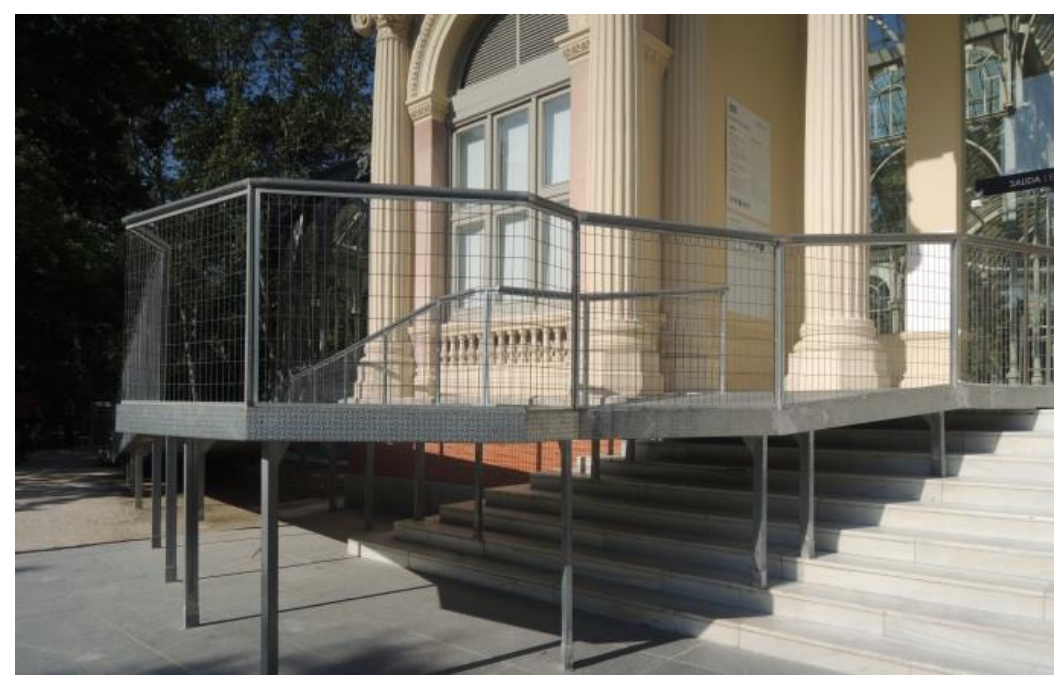

Figura 16 - Rampa de Acesso ao Palácio de Cristal. Fonte: Arquivo Pessoal.

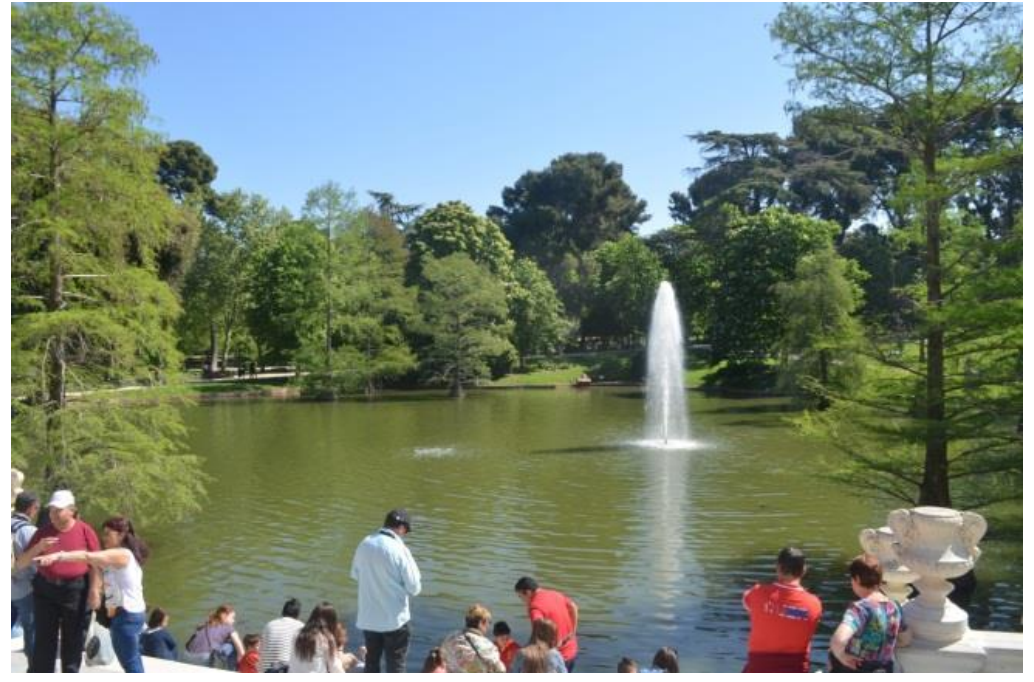

Figura 17 - Lago situado em frente ao Palácio de Cristal. Fonte: Arquivo Pessoal. 


\section{Palácio de Velazquez}

Foi projetado pelo arquiteto Ricardo Velazquez Bosco, construído entre os anos de 1881 a 1883 a fim de abrigar a exposição nacional de mineração. O edifício é coberto com abóbadas de ferro e vidro, que permitem iluminar as salas de forma natural. Possui planta de $73,8 \mathrm{~m}$ por $28,7 \mathrm{~m}$, foram empregados tijolos de duas cores na sua construção, além de utilizar de azulejos da Real Fábrica de La Moncloa. Hoje em dia, o edifício pertence ao Ministério da Cultura e é usado como sala de exposições temporárias do Museu Nacional Centro de Arte Reina Sofia (Figura 18).

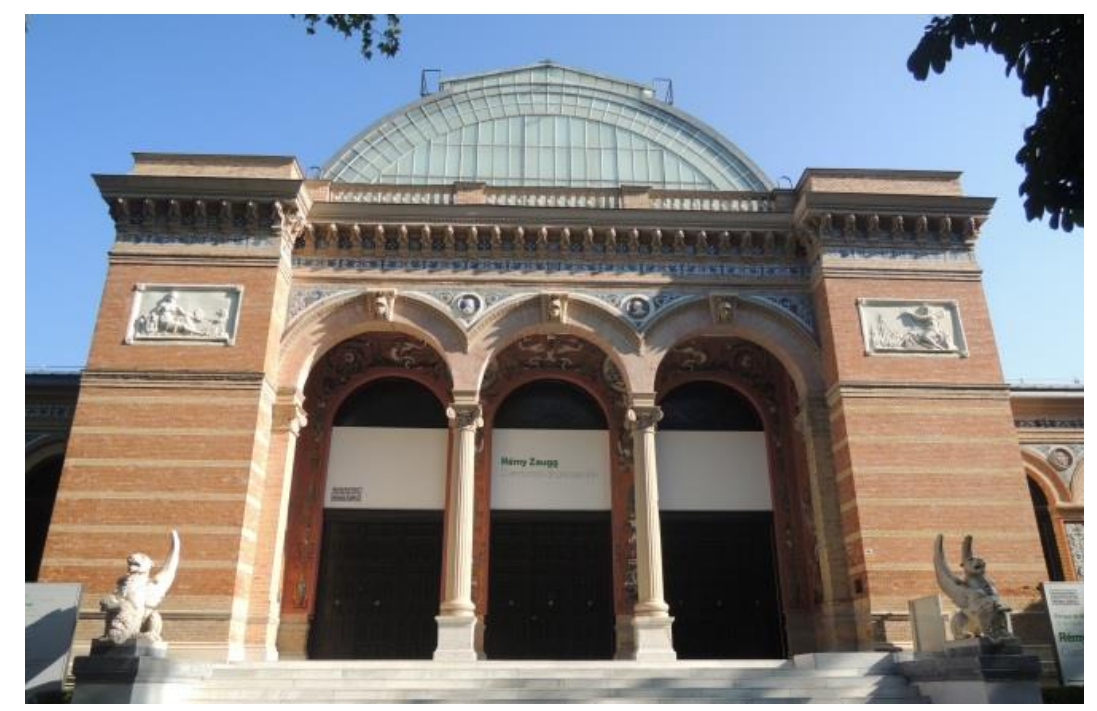

Figura 18 - Fachada do Palácio de Velazquez.Fonte: Arquivo Pessoal.

\section{Estanque Del Retiro}

Construído em 1694, o Estanque servia para receber espetáculos aquáticos e passeios do rei. Antigamente era conectado por um rio até a Real Fábrica de Porcelana da China e a ermida de Santo Antônio de los Portugueses, descendo o Passeio de Coches em direção à Praça do Anjo Caído. Neste período, havia uma ilha central com formato elíptico, que servia para realizar apresentações teatrais e musicais. Contava também com um estaleiro próprio para construções navais. No final do séc. XVIII as águas cobriram a ilha central do estanque.

A pedido de Fernando VII, em 1817, o arquiteto Isidro González Velázquez construiu um novo cais com um enorme arco, por onde passavam os barcos reais, e uma barreira de colunas de pedra, que circundava a lagoa. No verão de 1867, durante o reinado de Isabela II, o estanque foi aberto ao público, que alugava barcos 
coletivos de remo, canoas, bicicletas de água e até mesmo um pequeno barco a vapor. No começo do séc. XX, levantou-se um monumento em homenagem a Afonso XII. Hoje é frequentado pelos madrilenhos para tomar sol e usar os barcos (Figuras 19 e 20).

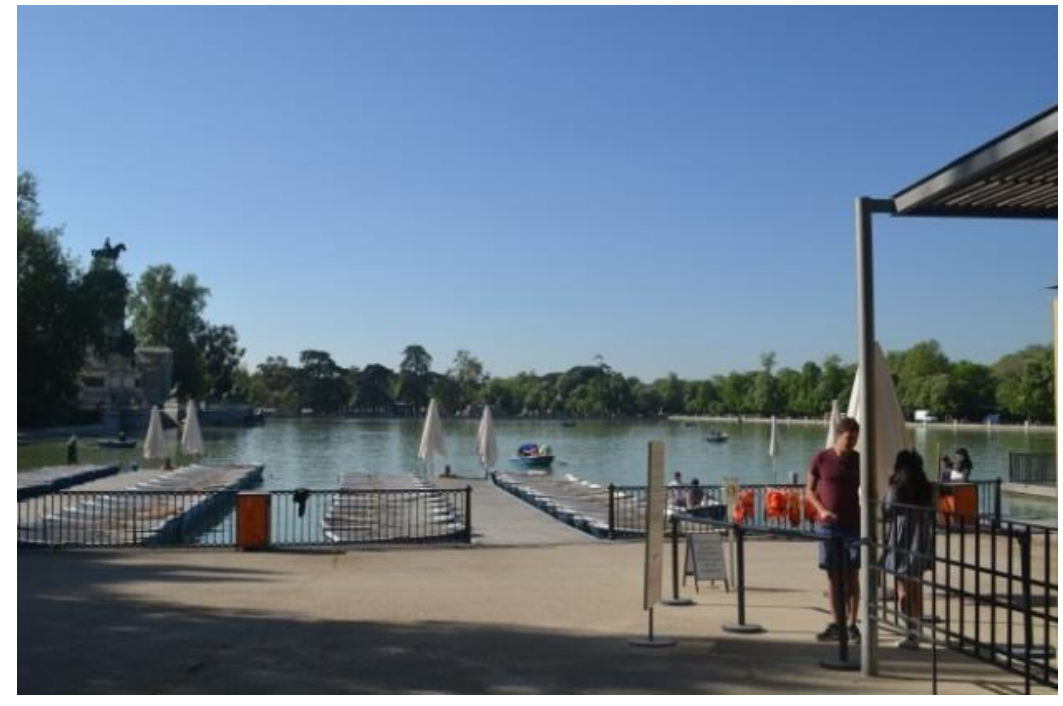

Figura 19 - O Estanque. Fonte: Arquivo Pessoal.

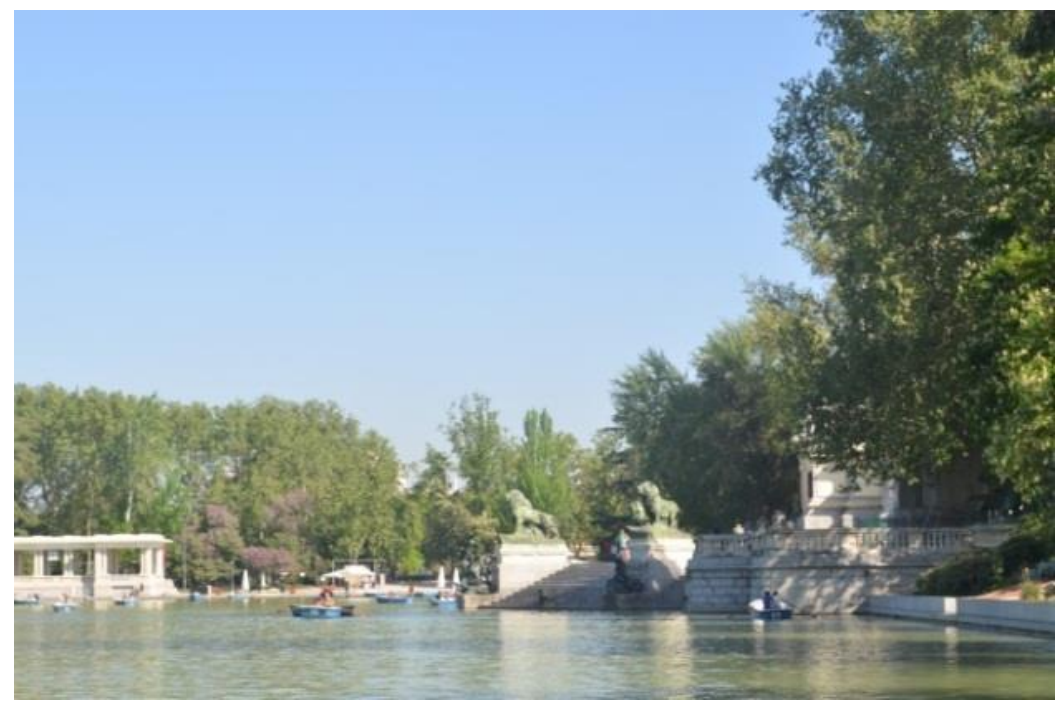

Figura 20 - O Estanque e estátuas. Fonte: Arquivo Pessoal.

\section{Monumento de Afonso XII}

Erguido em 1902, o monumento de Afonso XII foi idealizado por Grases Riera e concluído por Teodoro Anasgasti. Foi, inicialmente, apoiado em um pedestal de madeira pintado de verde e amarelo. Em 1927 o mesmo passou a ser de pedra e assim se mantém até hoje (Figura 21). Sua base em forma de cruz foi colocada em 
uma escadaria de dez degraus, além de colunas e esculturas diversas, acima disso foi colocada a estátua do rei montado em seu cavalo. Ao seu redor está situada a Plaza de España, que hoje atrai diversas pessoas (Figura 22).

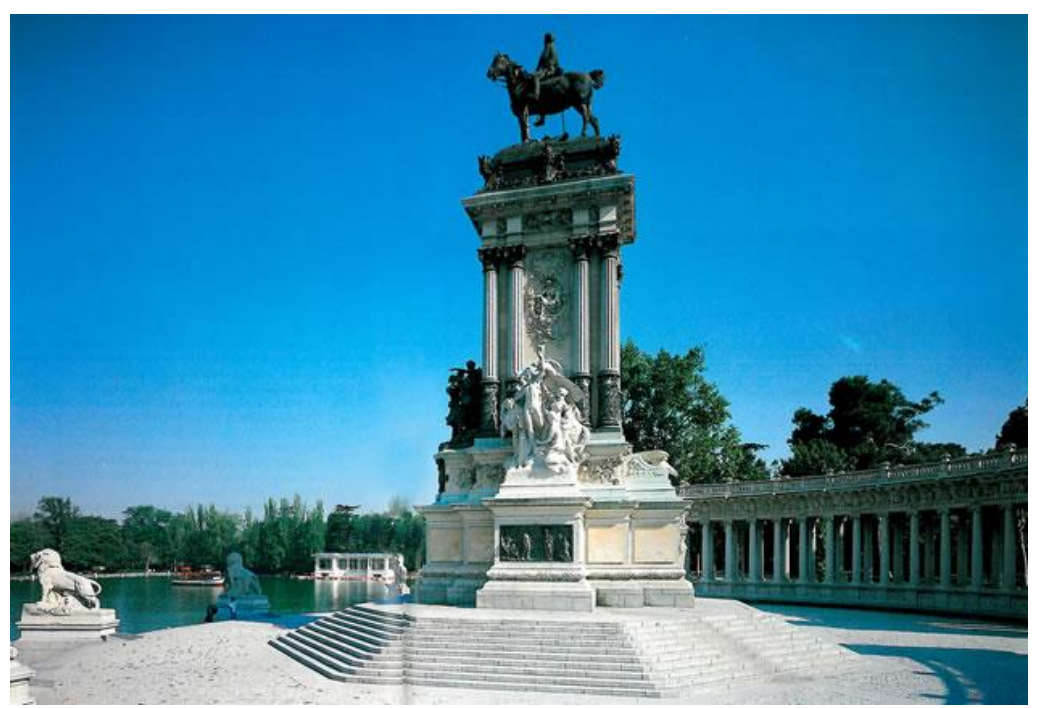

Figura 21 - Monumento Afonso XII. Fonte: https://goo.gl/Y67oPs, acesso em 25 de agosto de 2017.

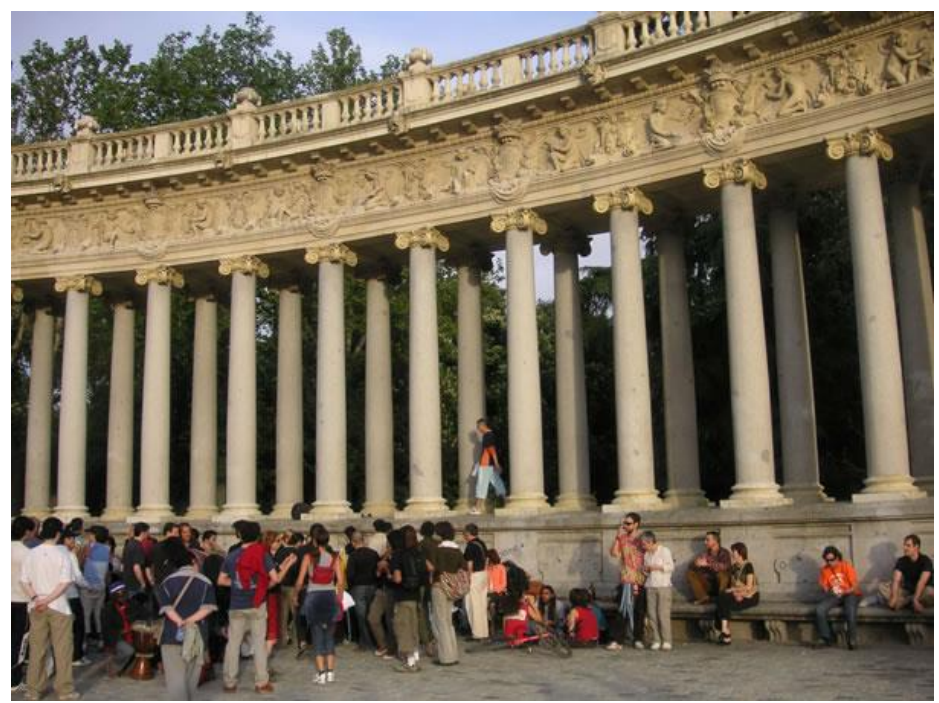

Figura 22 - Pessoas ao redor da banda. Fonte: https://goo.gl/Y67oPs, acesso em 25 de agosto de 2017.

\section{Biblioteca Pública Municipal Eugênio Trías}

Projetada pelos arquitetos Sebastián Araujo e Jaime Nadal, foi inaugurada em 29 de abril de 2013. Para corresponder ao programa de biblioteca foi elaborada a recuperação de dois grandes cômodos do Wild Animal House. O prédio, que hoje pertence à biblioteca, originalmente comportava parte da coleção particular de 
animais (menagerie) de Fernando VII (Figura 23). Foi dedicada a Eugenio Trías por ser considerado um dos grandes filósofos espanhóis do século XX. Além das excelentes instalações, tem um sistema de empréstimo de livros, músicas e filmes. É confortável e tem espaço para atender todas as idades, inclusive crianças. É um lugar de estudo e consulta de livros físicos e virtuais com acesso a computadores.

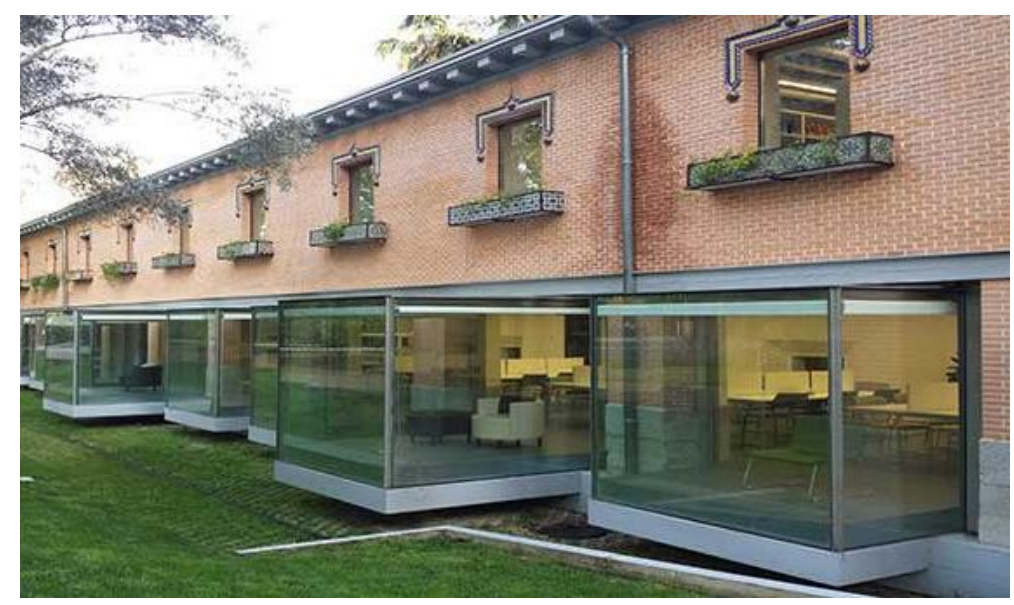

Figura 23 - Biblioteca. Fonte: https://goo.gl/oXZoJW, acesso em 25 de julho de 2017.

\section{El Paseo de Coches}

Financiado pelo Duque de Fernán Núñez, o Paseo de Coches foi inaugurado em 1873, sendo apontada como via central do parque. Pertence ao período da Primeira República e originalmente foi pensado para passeios de carruagem ou a cavalo, mas, em 1885, foi permitido o passeio de bicicleta. Conforme foram surgindo os automóveis, eles também passaram a percorrer esse passeio (Figura 24), sendo esse advento o motivo do nome do percurso.

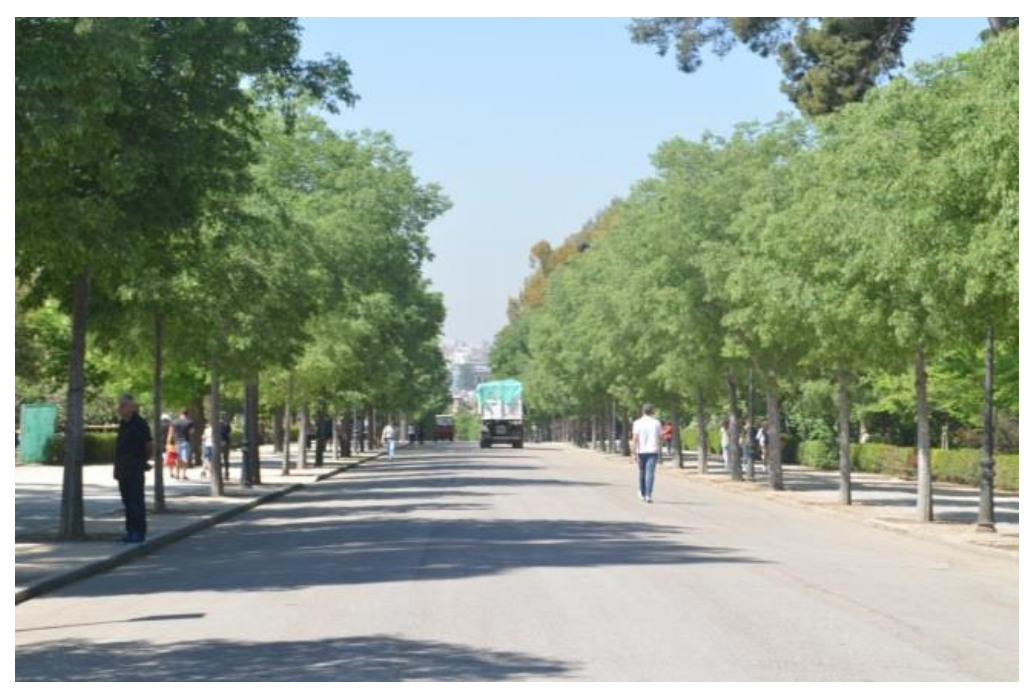

Figura 24 - El Paseo de Coches. Fonte: Arquivo Pessoal. 


\section{Fuente Egipcia}

Foi desenhada por Isidro González Valázquez em 1819, por ordem de Fernando VII, e construída em 1850 por Alfonso Rodriguez. Com a ideia de embelezar o lado leste do Grande Estanque, esta fonte tem uma estrutura semelhante à de um frontão em que se abre um nicho que contém uma enorme vasilha cuja tampa esta decorada com uma cabeça egípcia. Essa vasilha representa um vidro de vísceras, que era usado pelos antigos egípcios para depositar as vísceras dos defuntos no processo de mumificação. Debaixo existe uma torneira que escorre água na pia. A fonte foi realizada em granito cinzento combinado com tijolos (Figura 25).

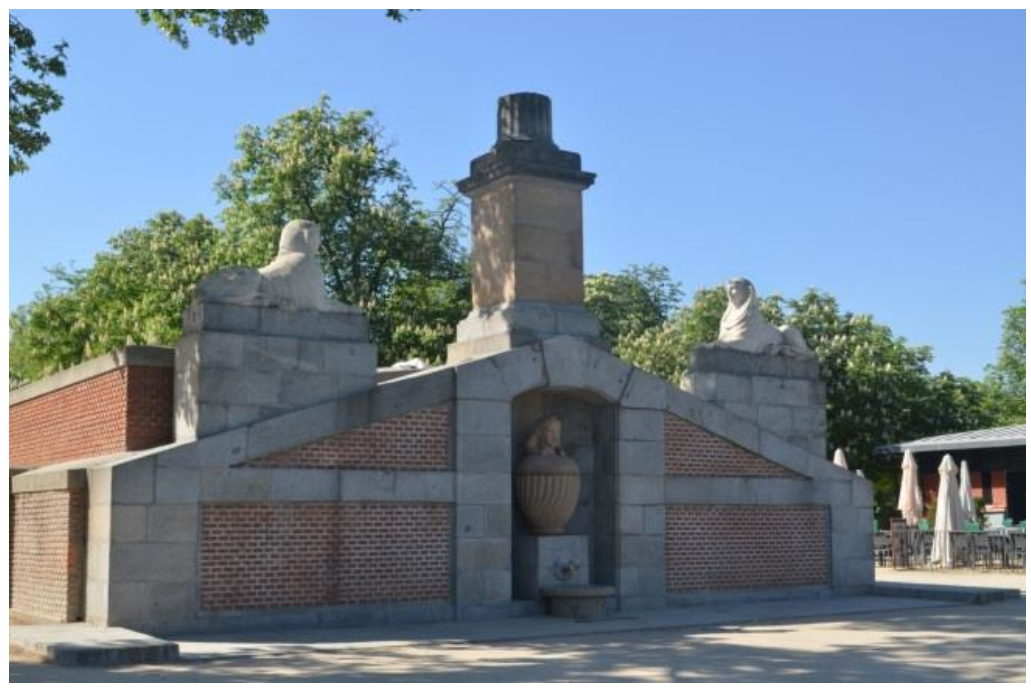

Figura 25 - Fonte Egípcia. Fonte: Arquivo Pessoal.

\section{Puerta de la Independencia e Fuente de la Puerta de la Independencia}

Projetada por José Urioste, foi instalada em 1885 utilizando-se da porta do jardim romântico Casino de la Reina. Tem dois grupos de colunas nos estilo Dórico, sobre as quais se encontram duas estátuas de cupidos (Figura 26). Sendo esta uma das principais entradas do parque, está situada na Praça da Independência próxima à porta de Alcalá, a forma mais fácil de acesso a esse setor é através do metrô, descendo na estação do parque. A partir dessa entrada, também se chega com facilidade ao Estanque. Uma vez passada a porta, existe a Praça da Independência com uma fonte (Figura 27). Esse conjunto ornamental é formado por uma fonte de parede com um tanque retangular, possui $9 \mathrm{~m}$ de largura e $1,1 \mathrm{~m}$ de altura. A fonte semicircular foi construída com granito, destacando-se da parede de tijolos 
vermelhos. Ao redor do tanque retangular existem jardineiras onde as flores são plantadas de acordo com a estação do ano.

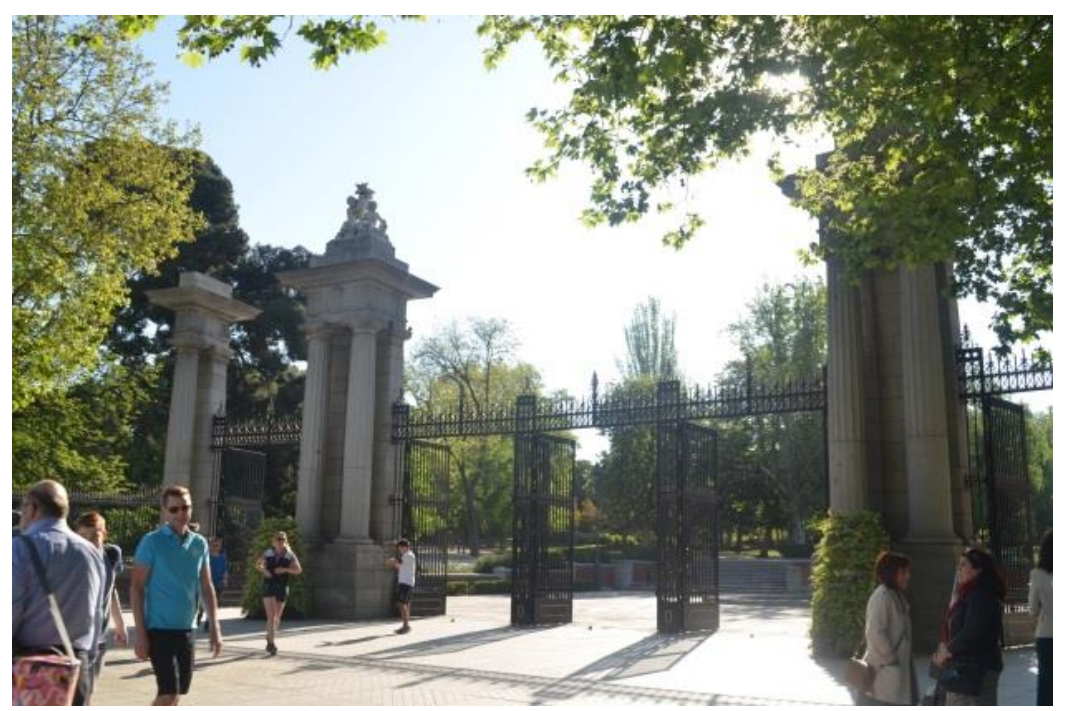

Figura 26 - Porta da Independência. Fonte: Arquivo Pessoal.

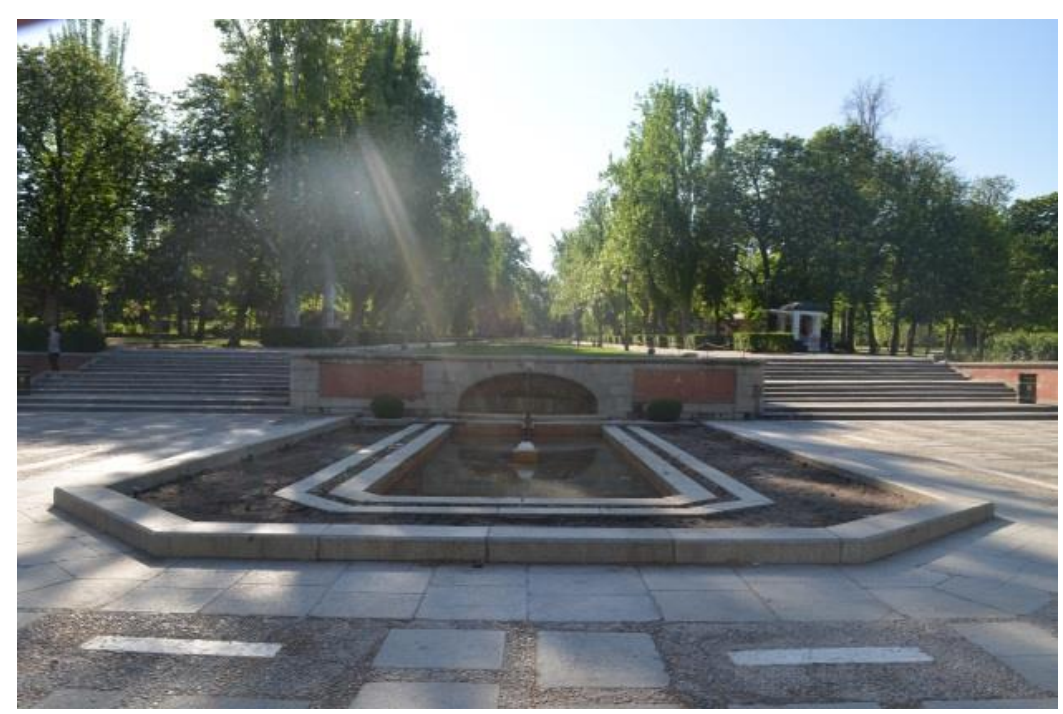

Figura 27 - Fonte da Independência. Fonte: Arquivo Pessoal

\section{El Ángel Caído}

Projetada pelo duque Fernan Nunez e esculpida em gesso por Ricardo Bellver, foi erguida em 1876. Um ano depois, em 1877, participou da Exposição Nacional de Belas Artes, onde foi premiada. Passou para custódia do estado, e nesta época, foi banhada em bronze para poder participar da Exposição Universal de Paris. Após sua exposição, foi para o Museu Nacional, onde, em 1879, o diretor Benito Soriano Murillo quis expor a obra ao ar livre para o público. Esta escultura 
gerou muitas polêmicas, principalmente na comunidade mais conservadora, que via de forma inconcebível colocar em um parque uma obra com este tema (Figura 28).

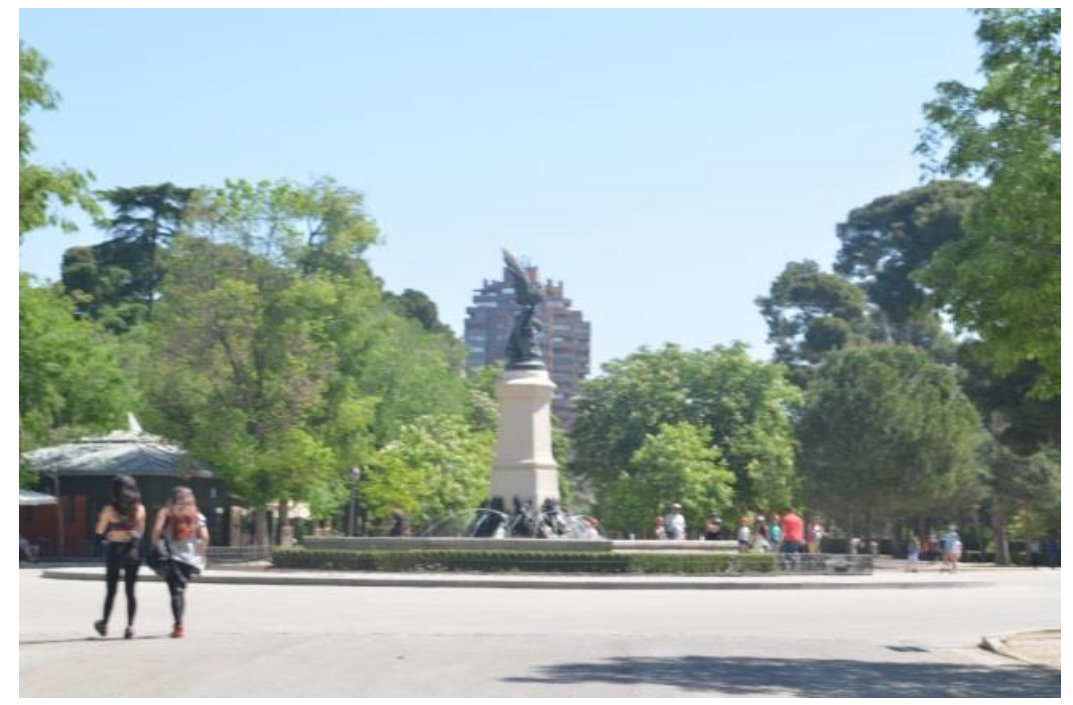

Figura 28 - O Anjo Caído. Fonte: Arquivo Pessoal.

\section{Feira do Livro}

A Feira do Livro é um evento típico do Paseo de Coches no Retiro (Figura 29). Cada ano na primavera, as cabines são montadas e desmontadas depois de três semanas. Desde 1933, o evento cultural atrai milhares de visitantes, que em cada ano um país é homenageado. A 76 edição aconteceu em maio e junho de 2017 e o país escolhido foi Portugal. A realidade cultural portuguesa se materializou em todas as atividades relacionadas como a literatura, o cinema, a música, que durante a feira, serviram para mostrar a riqueza e exaltar os valores relativos à produção cultural deste país.

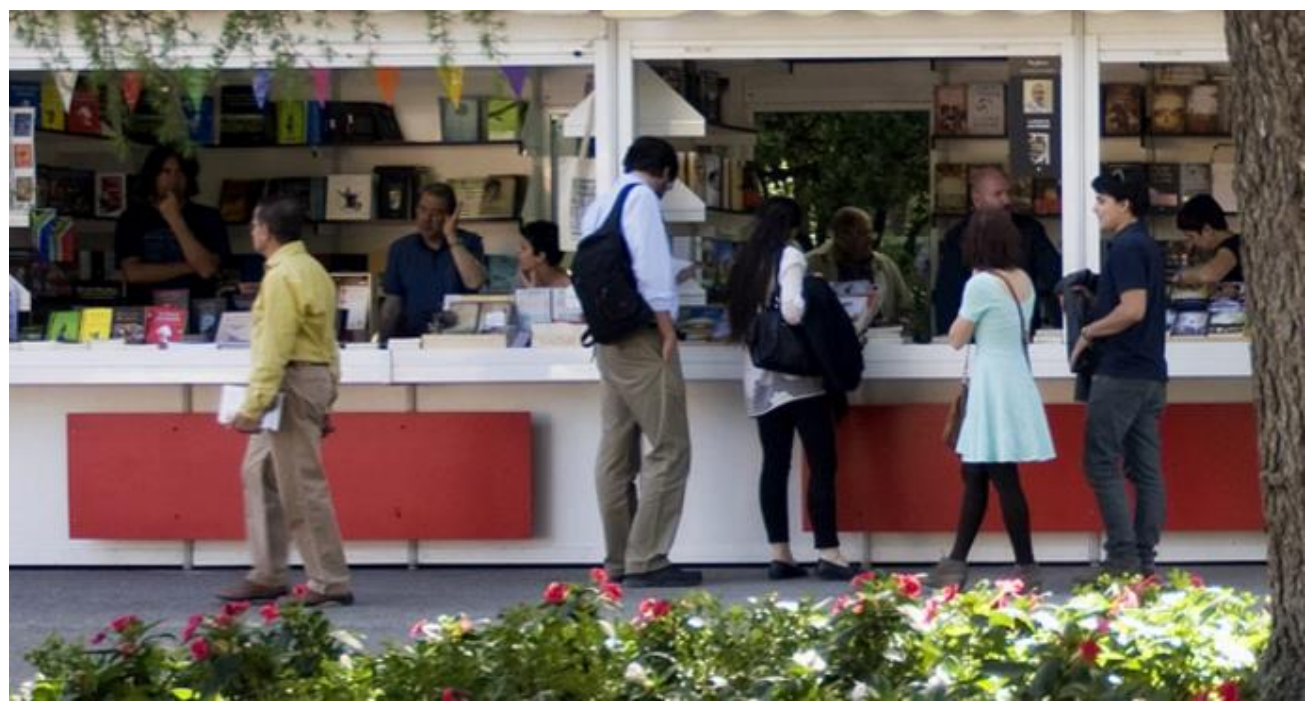

Figura 29 - Feira do Livro. Fonte: https://goo.gl/u9Dpe7, acesso em 25 de agosto de 2017. 


\section{La Rosaleda}

A Rosaleda del Retiro é uma área com tratamento paisagístico no estilo francês. A iniciativa foi do prefeito de Madrid, Carlos Prats, que queria dar um ar mais elegante a esta parte do parque. Foi projetada em 1915 por Cecilio Rodríguez, Jardinero Mayor de la Villa. Ele tomou como modelo outros jardins europeus semelhantes e, em particular, o do Bois de Boulogne em Paris. Apesar da perfeição de seus caminhos recortados e sua grande variedade de rosas, após a reconstrução do recinto, devido à sua destruição durante Guerra Civil, foi decidido construir um nova Rosaleda no Parque del Oeste. A localização da Rosaleda del Retiro é mais acessível para o visitante. O jardim é cuidadosamente mantido e limpo.

Composto por mais de 4.000 rosas dispostas em canteiros de flores, a época de maior afluência é a primavera, quando as rosas florescem. Cada parterre tem uma placa de identificação da rosa que abriga. A Rosaleda del Retiro ocupa um pouco menos de um hectare, tem uma forma elíptica e o layout de seus canteiros é simétrico. É delimitada por uma cobertura perimetral com quatro aberturas que servem de acesso ao recinto. No centro, há uma pequena lagoa e, para os lados, duas fontes de calcário branco realizam o movimento da água a fim de dar ao ambiente uma atmosfera mais relaxante (Figura 30 ).

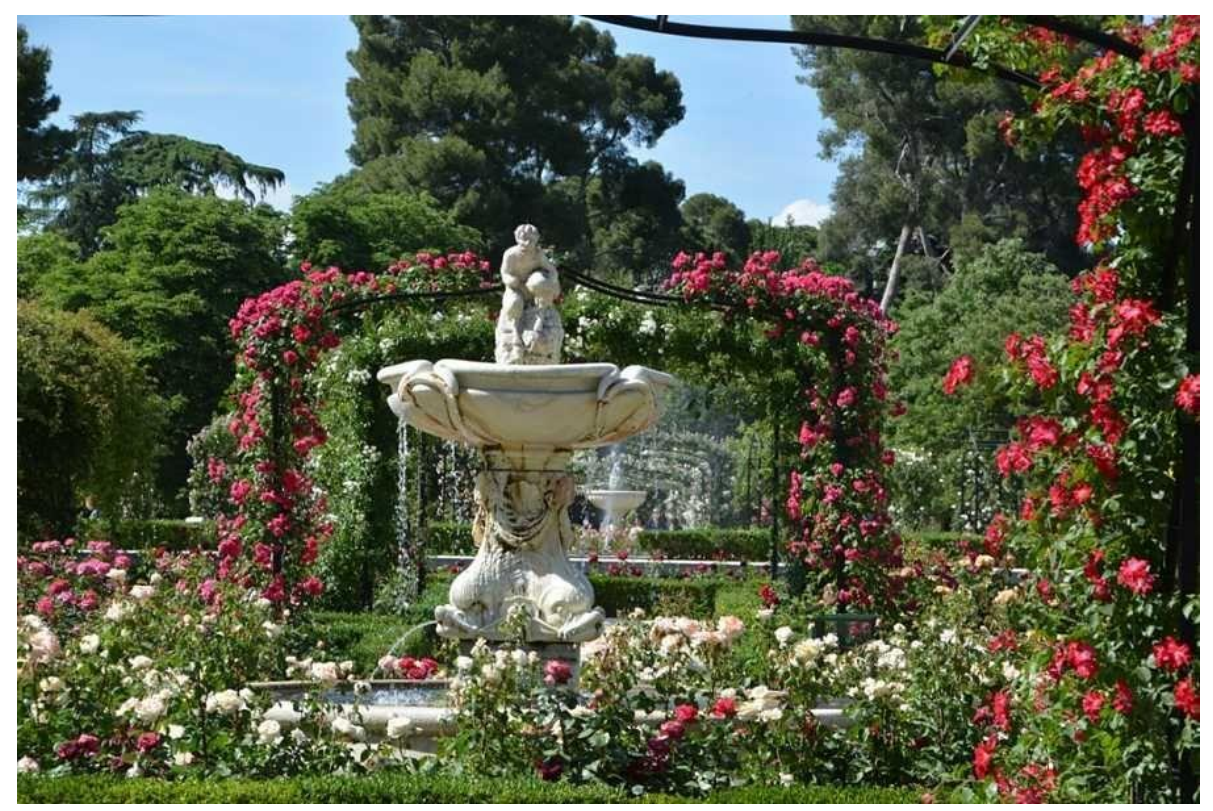

Figura 30 - La Rosaleda.

Fonte: https://goo.gl/joD3dx, acesso em 9 de setembro de 2017. 


\subsection{Manutenção}

O Parque El Retiro abre às $6 \mathrm{~h}$ e fecha às $22 \mathrm{~h}$ no inverno e no verão abre às $6 \mathrm{~h}$ e fecha às $24 \mathrm{~h}$. Durante o dia inteiro, é realizada a manutenção e conservação do paisagismo, da iluminação, do saneamento, da segurança e limpeza. Existem duas principais plantações no ano: uma na primavera e outra no verão, pois, em cada época, cada área de espécies requer cuidados específicos ao executar a jardinagem. Cerca de $5 \%$ do gramado do parque é renovado a cada ano.

Desde 2014, a maior parte dos 118 hectares do parque é gerida de forma integral por cerca de 100 trabalhadores de uma empresa terceirizada (Figuras $31 \mathrm{e}$ 32), embora haja algumas áreas onde as atividades de jardinagem e manutenção são compartilhadas com trabalhadores municipais. O parque conta com auxílio de agrônomos, técnicos agrícolas e florestais, técnicos em obras públicas, engenheiros civis, especialistas em jardinagem e paisagismo. A prefeitura de Madrid confinou serviços de conservação integral, jardinagem, limpeza, segurança, mobiliário urbano, redes de iluminação e saneamento, irrigação e fontes ornamentais às empresas especializadas. Aplicando sua política de qualidade, meio ambiente e sustentabilidade, como o uso de máquinas e veículos elétricos para minimizar as emissões de $\mathrm{CO} 2$ e ruído (Figura 33), faz com que o parque seja mantido de forma ecológica.

Foi desenvolvido um software para monitorar indicadores de qualidade. Através desse monitoramento online, é capaz de obter informações como: o comprimento da grama ou a qualidade da água das fontes ornamentais. Também é utilizada uma ferramenta de gestão, que se aplica a áreas verdes para controle de custos e recursos. Há a utilização de um georadar (Figura 34), que, associado a outro software, permite gerar imagens do estado das raízes das árvores, sendo possível estudar e analisar sua "saúde" e agendar trabalhos de arboricultura. O trabalho de campo inclui o controle e risco da altura de uma árvore, as doenças, e a poda. Os restos da poda são levados à unidade de compostagem onde são transformados em adubo que é reutilizado em outros parques de Madrid.

Um dos pontos fortes da gestão é o uso eficiente da água por sistema de irrigação por telegestão, automação centralizada em um computador, que pode ser 
controlado a partir de um dispositivo com ligação à Internet, poupando água, custos e tempo.

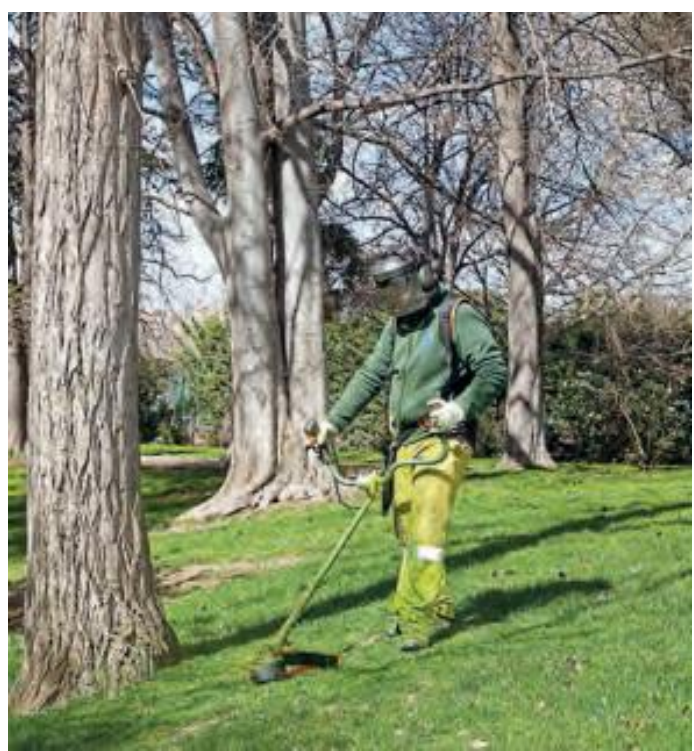

Figura 31 - Trabalhador cortando a grama. Figura 32 - Trabalhador varrendo o chão.

Fonte: https://goo.gl/w1fn6Y, acesso em 09 Fonte: https://goo.gl/w1fn6Y, acesso em 09 de de setembro de 2017.

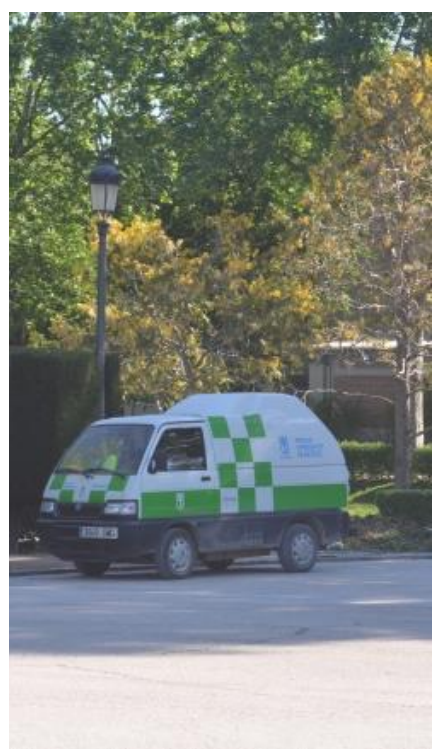

Figura 33 - Veículo.

Fonte: Arquivo Pessoal.

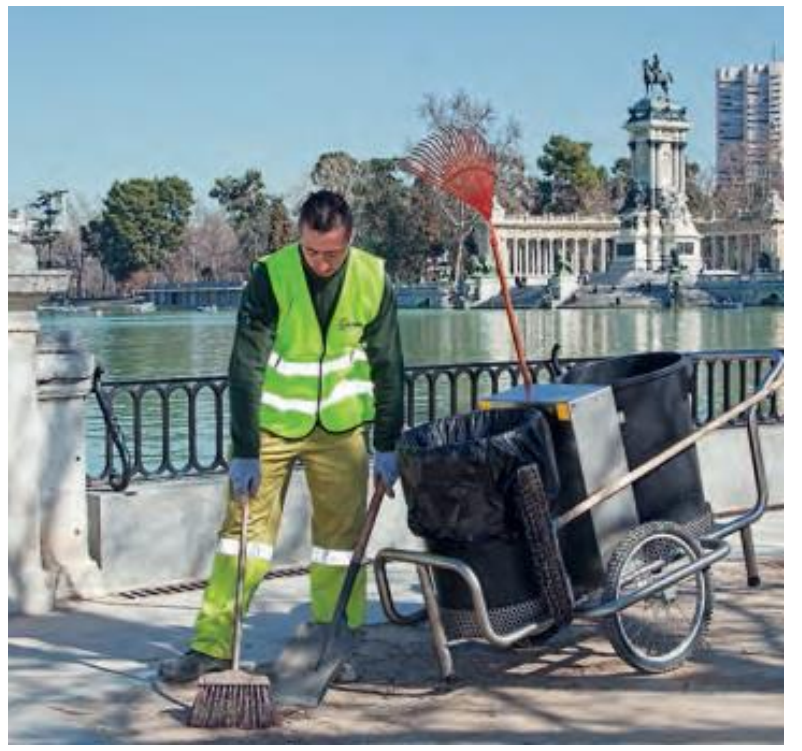
setembro de 2017.

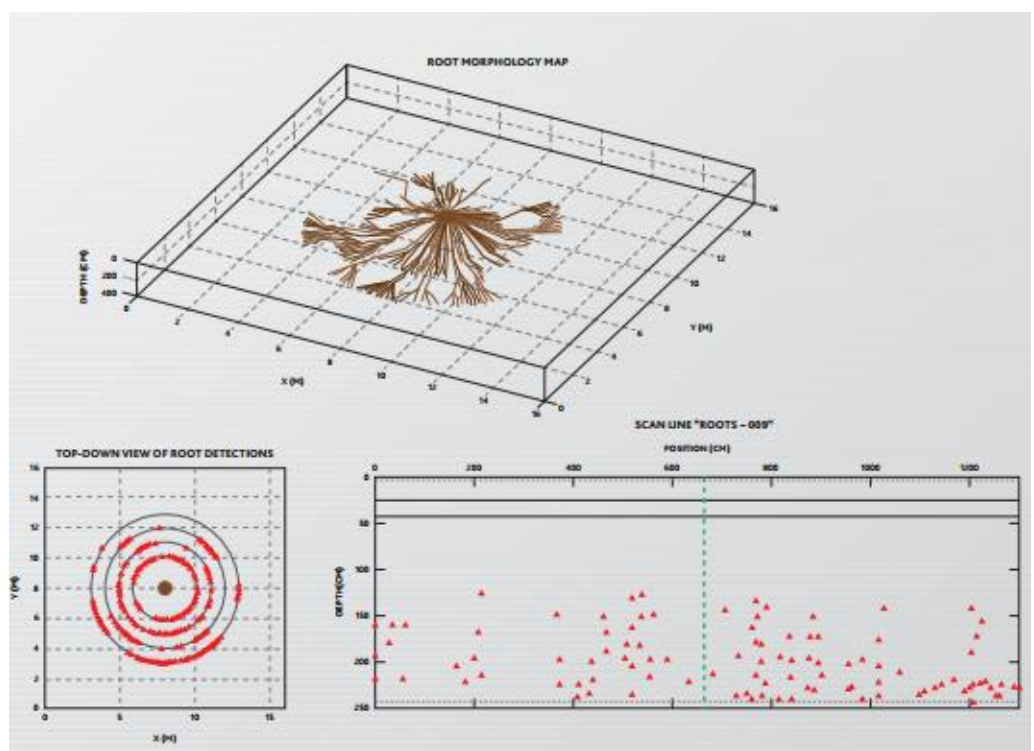

Figura 34 - Imagem gerada pelo georadar.

Fonte: https://goo.gl/w1fn6Y, acesso em 09 de setembro de 2017. 


\section{PARQUE DEL OESTE}

\subsection{História}

O Parque del Oeste foi originalmente concebido na década de 1890 por Celedonio Rodrigañez y Vallejo, que na época era responsável pelos jardins e parques da cidade. $\mathrm{O}$ arquiteto paisagista converteu a área - antigo depósito de lixo - em um grande jardim, abrindo a possibilidade de uso público desse espaço em Madrid. Foi inaugurado oficialmente em 1905. Curiosamente no princípio não era permitido comer, nem sentar no gramado, então instalaram quiosques de música e um cinema ao ar livre. Diferente dos dias de hoje, o parque era frequentado, sobretudo pela burguesia.

Foi recriado durante a década de 1940 depois que o parque foi danificado e negligenciado durante Guerra Civil Espanhola, sofrendo contínuos bombardeios e confrontos corpo a corpo em trincheiras. $\mathrm{O}$ parque tem caráter e paisagens monumentais com traçado inglês, fontes e caminhos curvos de inspiração naturalista (Figura 35). Há uma vasta variedade de espécies vegetais, destacando-se uma singular população de coníferas, em contraste com as árvores frondosas.

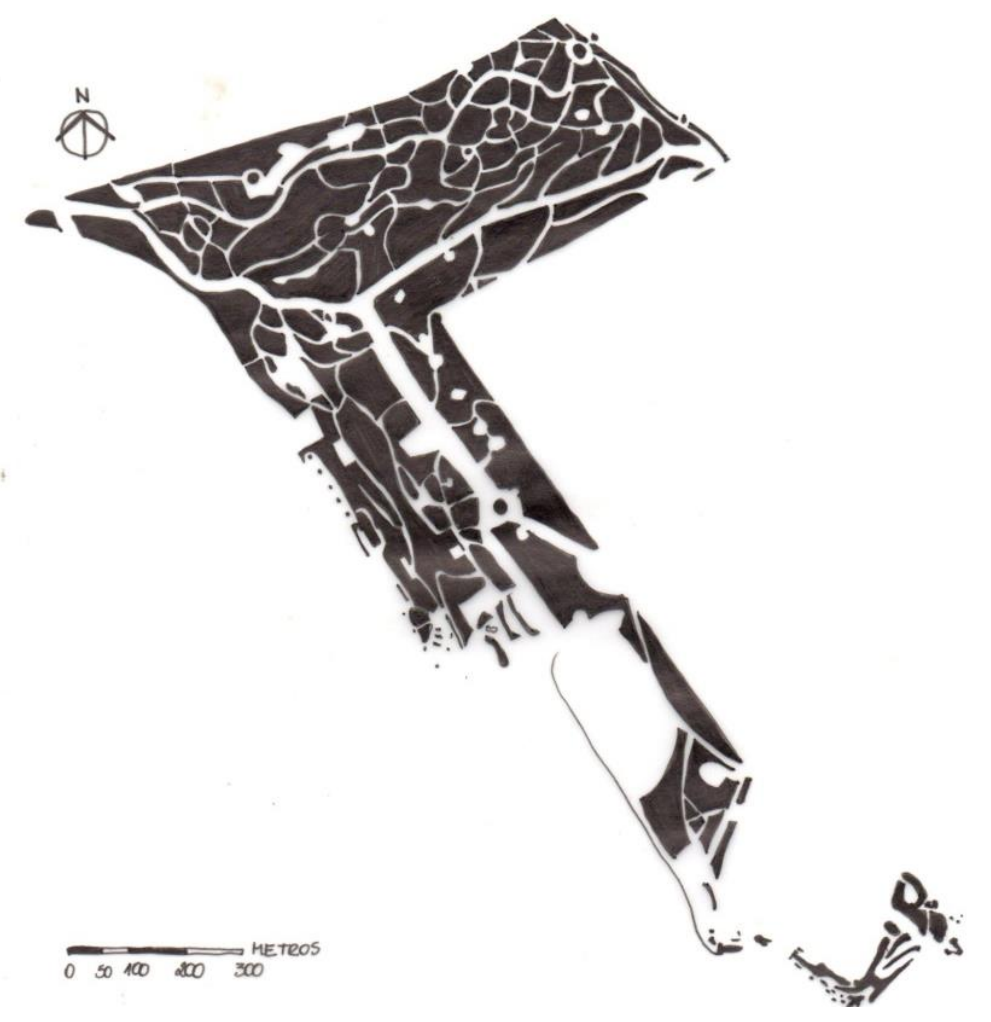

Figura 35 - Mapa do Parque del Oeste. Fonte: Arquivo Pessoal. 


\subsection{Usos}

\section{La Rosaleda}

La Rosaleda começou a ser construída em 1955, mas foi inaugurada em 24 de maio de 1956 para celebrar o I Concurso Internacional de Novas Rosas na Villa de Madrid. Foi projetada pelo Jardineiro da prefeitura de Madrid, Ramon Ortiz Ferré, que se inspirou nas roseiras de Paris, Roma e Genebra do final do século XIX e início do século XX, bem como na Rosaleda do Parque El Retiro projetado em 1915 por seu mestre Cecilio Rodríguez. Desde a sua criação, celebra-se em cada mês de maio o mesmo concurso. As variedades de rosas vencedoras tornam-se parte da coleção permanente do jardim. Em 2006 foi premiada pela Word Federation of Rose Societies com o premio "Award of Garden Excellence", reconhecida como uma das roseiras mais excepcionais de todo o mundo.

O jardim Rosaleda acolhe mais de 500 variedades de rosas de todo o mundo (Figura 36). Além de suportar uma coleção tão importante de rosas, uma parcela serve de teste para ver o comportamento de tais rosas no clima da Espanha. De todos os lugares do parque, este é o único lugar que fecha fora da programação do restante do parque e está sujeito a um maior cuidado.

O jardim é organizado por polígonos com rosas de cores e fragrâncias diferentes. Ele contém várias pérgolas com rosas trepadeiras e uma fonte, tornandose um dos lugares mais silenciosos do parque, pois poucas pessoas costumam visitá-lo, exceto durante o mês de maio, quando se tem rosas. Na primavera, a Rosaleda torna-se um lugar único para passar um bom tempo entre cores e fragrâncias de suas rosas. Nos lados, encontram-se alguns arcos e galerias (Figuras 37 e 38). Uma das atrações da Rosaleda é o Concurso Popular Rosa em Madrid, que é comemorado todos os anos no mês de maio, quando as roseiras estão em plena floração. Madrilenos e visitantes caminham pelo jardim e, entre os canteiros marcados com uma faixa amarela, escolhem sua rosa favorita. 


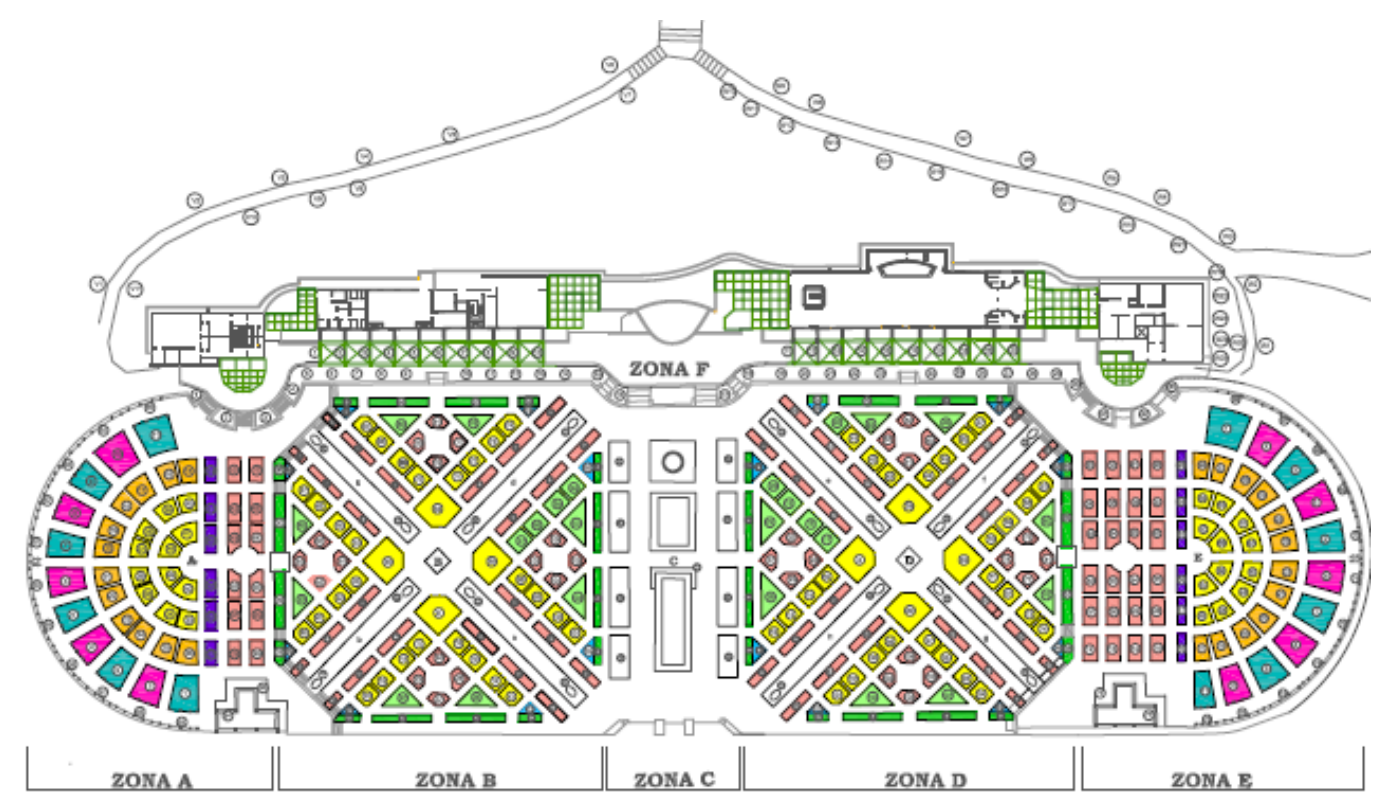

Figura 36 - Zoneamento da Rosaleda.. Fonte: https://goo.gl/1gTWx2, acesso em 20 de agosto de 2017.

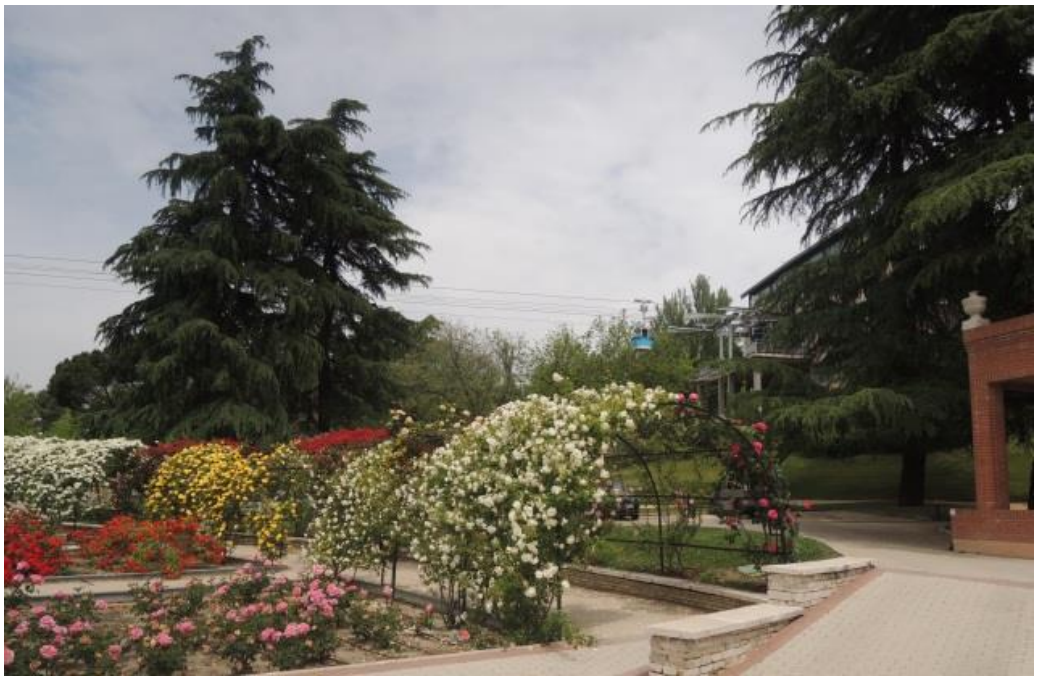

Figura 37 - La Rosaleda. Fonte: Arquivo Pessoal.

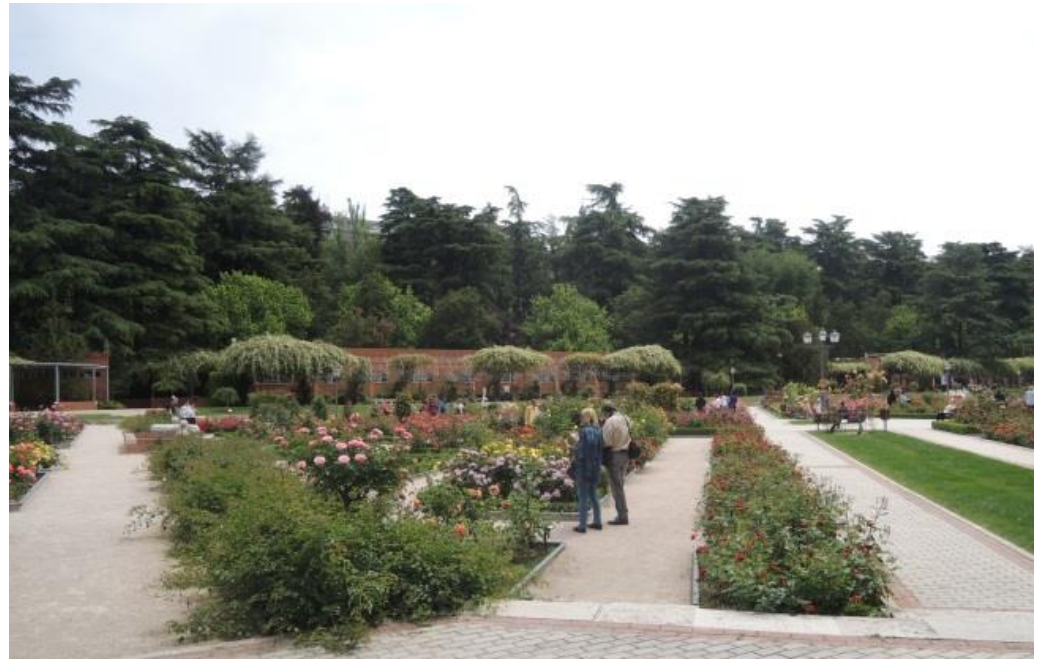

Figura 38 - La Rosaleda. Fonte: Arquivo Pessoal. 


\section{Templo de Debod}

Construído no início do século II a.C a pedido do rei de Meroe, Kushita Adijalamani, o templo era dedicado ao culto dos deuses Amón, o pai do vento, e a Isis, a deusa da maternidade, tendo sua localização original no sul do Egito, na região da Baixa Nubia. A capela construída por Adijalamani constitui o núcleo original do templo de Debod, nas suas paredes decoradas com cenas em relevo, mostram o rei Meroitic fazendo oferendas aos deuses egípcios. O rei Ptolomeu VI e seu sucessor estenderam o santuário original, acrescentando-lhe novas capelas, um terraço e um pilão, fazendo da pequena capela original, um templo egípcio. Após a vitória sobre Marco Antonio e Cleópatra, Roma conquistou o Egito em 30 a.C e durante este período, o templo foi decorado com cenas que mostravam o imperador romano Augusto. No século VI, após a conversão de Nubia ao cristianismo, o templo foi fechado e abandonado.

Em 1898, começou a construção de uma barragem para regular o fluxo do Nilo, esta barragem teve consequências para templos e sítios arqueológicos, pois eles foram submersos às águas. Os relevos perderam suas cores e pedras submetidas à ação da água, se deterioraram ainda mais severamente. Ao mesmo tempo, o Departamento de Antiguidades empreendeu a restauração de vários templos, incluindo Debod. Em 1954, o governo de Gamal Násser anunciou a construção de uma nova barragem de Aswan, mas como consequência ela iria formar um vasto pântano. Enquanto a nova barragem começou a ser construída, as equipes de arqueólogos, arquitetos, engenheiros e restauradores foram incubidos de retirar os templos e remover para um lugar seguro, sendo o Templo de Debod o primeiro a ser resgatado no verão de 1960.

A Espanha contribuiu para a campanha de resgate da Nubia, financeira e cientificamente. No século XX, o governo egípcio deu para a cidade de Madrid o Templo de Debod, ele foi transportado, reconstruído pedra por pedra e aberto em sua localização atual em 1972. A reconstrução feita em Madrid foi mantida na orientação do seu local de origem, de leste a oeste, sendo composto por um edifício principal e dois portais de pedra. No seu interior há informações sobre a mitologia e a sociedade egípcia, possui explicações dos hieróglifos e suas paredes estão 
decoradas com relevos. Ao redor do templo foi construído um espelho d'água, simbolizando o Rio Nilo (Figura 39).

Durante as primeiras décadas o templo em Madrid não era cuidado e até mesmo a área foi considerada insegura. Atualmente, o município está trabalhando para obter a melhor preservação do templo e reforçar a segurança. Por razões de conservação, a fim de manter a integridade ambiental consistente e estável do monumento, a visita dentro do templo está sujeita a restrições temporárias, apesar disso o Templo de Debod é um dos monumentos mais visitados do parque.

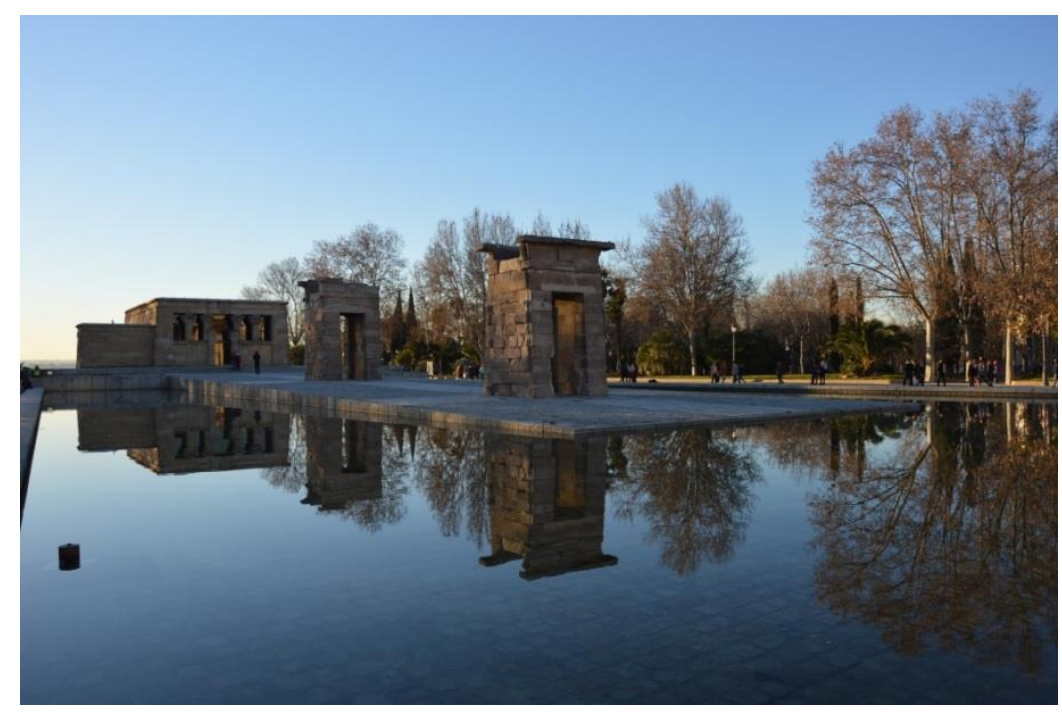

Figura 39 - Templo de Debod. Fonte: Aurora Tucci.

\section{Teleférico}

Construído originalmente para o parque de diversão no século XIX, foi transformado em uma forma de transporte. O passeio começa com um voo sobre o parque e o jardim Rosaleda, continua ao longo da antiga estação ferroviária Príncipe Pio. Depois de atravessar o rio Manzanares, entra na Casa de Campo, que é o principal pulmão verde da cidade, e termina seu percurso ao chegar à Praça dos Passos Perdidos. Do teleférico a cidade parece diferente. Por um lado, a antiga Madrid, o Ministério da Aeronáutica, o templo egípcio de Debod, os arranha-céus da Praça de Espanha, o Palácio Real com jardins estilo clássico do Campo del Moro, a Catedral de Almudena e a Igreja de San Francisco. Por outro lado, a Madrid moderna e majestosa com o Complexo das Quatro Torres e o Faro de la Moncloa. 
Sobrevoar a Casa de Campo é uma experiência única, da qual a partir da cabine pode ser vista a vastidão de uma ampla paisagem com espécies nativas. $O$ teleférico desliza por cima dos castanheiros, carvalhos, plátanos e salgueiros, enquanto se vê da cabine, o lago com seus barcos, o parque de diversões e um pouco além do zoológico (Figura 40). As cabines atingem uma altura máxima de 40 metros acima do solo e todo o passeio de $2.5 \mathrm{~km}$ leva um pouco mais 10 minutos a partir do seu ponto de partida. No final da viagem, há um restaurante e um bar.

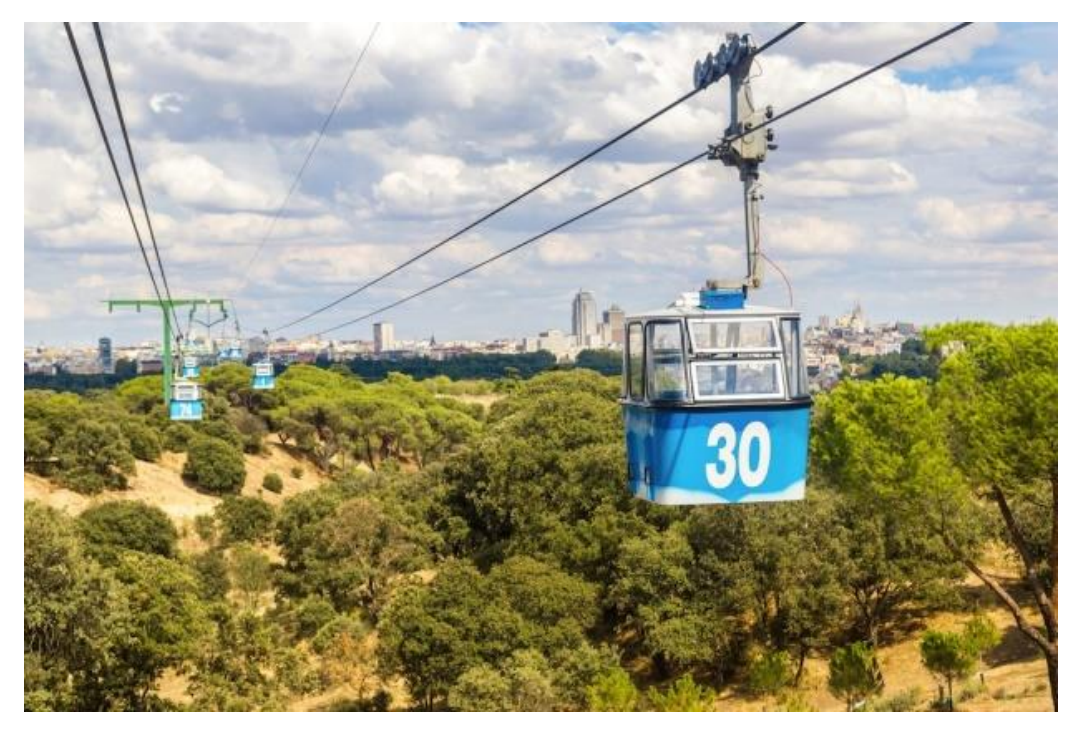

Figura 40 - Teleférico. Fonte: https://goo.gl/qcm7JE, acesso em 20 de agosto de 2017.

\section{Escuela de Cerámica la Tinaja e Escuela de arte Francisco Alcántara}

Em 1760, Carlos III fundou a fábrica de porcelana da China no Parque EI Retiro, que foi destruída durante uma guerra. Posteriormente, instalou uma fábrica de cerâmica no Parque del Oeste e desde 1877 a fábrica permanece neste local, sendo reconstruída e ampliada por Luiz Bellido e Leopoldo Ulled em 1935.

Acomodada em suas novas instalações está a Escola de Arte, fundada em 1911 pelo advogado, perito agrônomo, crítico de arte e erudito Francisco Alcántara. O edifício combina o estilo Neomudéjar da antiga fábrica e com o funcionalismo racionalista na ordem compositiva das fachadas, resultando em um conjunto simples e elegante de dois pavilhões (Figura 41). O pavilhão Flórida era usado como uma sala de exposições permanente, já o pavilhão Bellido era usado para estudos individuais e oficinas de fabricação. Em 1992, com a reabilitação de Joaquim Roldán 
Pascual, foi desenterrada a planta inferior do pavilhão Flórida, onde foram colocadas formas derivadas de abóbadas feitas de tijolo, que agregaram valor ao local, mas hoje este pavilhão foi alocado para a polícia municipal.

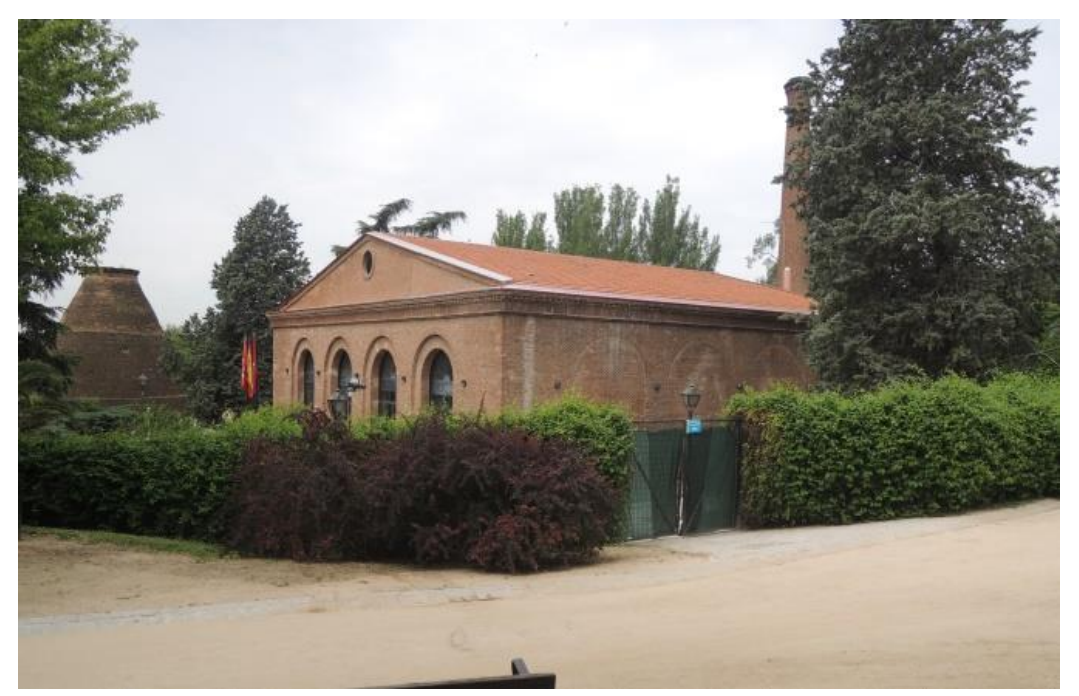

Figura 41 - Escuela de arte Francisco Alcántara. Fonte: Arquivo Pessoal.

\section{Monumento a Goya}

Há uma série de escadas que descem para a parte mais ocidental do Parque del Oeste, onde o parque é mais formalmente definido. A visão mais notável nesta área é um monumento moderno que homenageia Goya, um dos pintores mais famosos da Espanha (Figura 42).

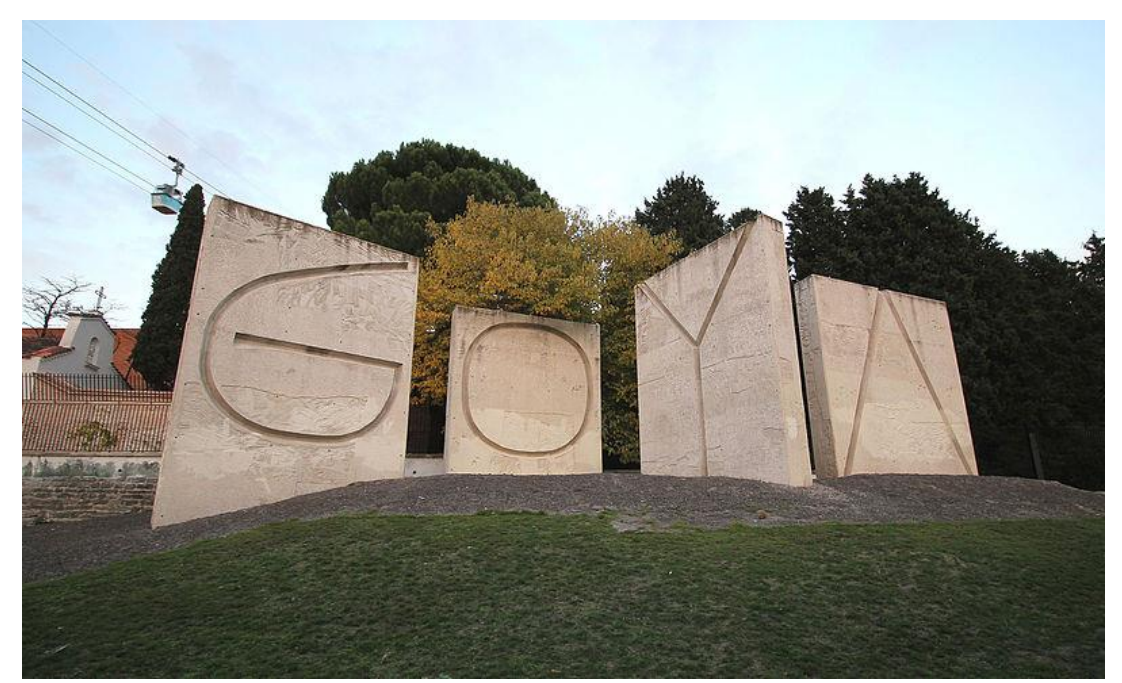

Figura 42 - Monumento a Goya. Fonte: https://goo.gl/2WLfSS, acesso em 20 de agosto de 2017. 


\section{Monumento Sor Juana Inés de la Cruz a Madrid}

Sor Juana Ines de la Cruz era uma freira e poeta Católica nascida no México e filha ilegítima de um militar espanhol influente. Ela escreveu boa parte do seu trabalho como uma freira na ordem de Jeronimas. Expoente da Idade de Ouro da literatura espanhola, ela cultivou o lírico, o sacramental, teatro e a prosa. Esta escultura foi um presente do povo mexicano para o povo de Madrid concedido em outubro de 1981 e atualmente está localizada em um pequeno jardim na Rua Ferraz, na entrada do Parque del Oeste junto à Praça de Espanha. Essa estátua é uma réplica da que se encontra no México e foi doada por Claustro Sor Juana Inés de la Cruz. É o trabalho do espanhol Enrique Fernández Criach em nome de um grupo de mexicanos que vivem em Madrid. Ela consiste em uma estátua de bronze representando a poetisa vestida com trajes religiosos e um rosário, sentada em uma cadeira na posição de escrever. A estátua fica em um pedestal de granito (Figura 43).

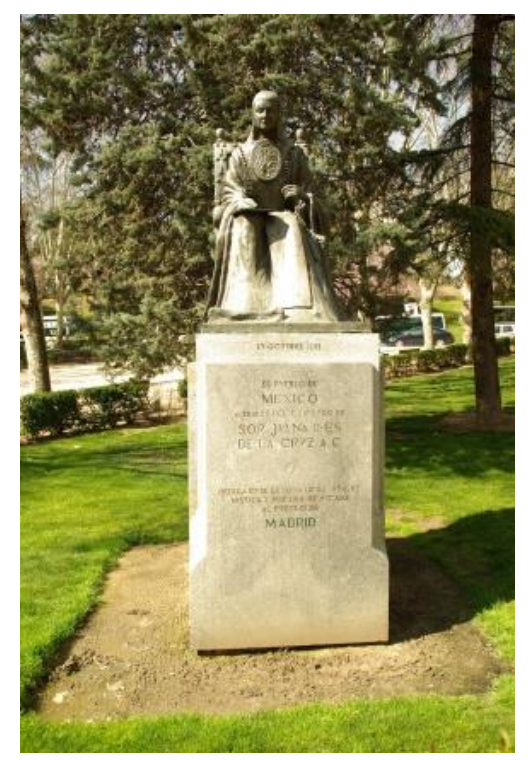

Figura 43 - Monumento Sor Juana Inés de la Cruz a Madrid. Fonte: https://goo.gl/Z8RwGq, acesso em 20 de agosto de 2017.

\section{Mirador de la Montaña de Príncipe Pío}

A montanha do Príncipe Pío é um dos lugares mais visitados no centro de Madrid, devido à sua localização ao lado da Praça de Espanha e às magníficas vistas que estão contempladas, já que em sua parte central está localizado o Templo de Debod (Figura 44 e 45). Originalmente, este lugar era denominado Huerta, 
Dehesa Florida ou os altos de San Bernardino, e fazia parte de uma grande fazenda do norte de Madrid. No final do século XVII, a propriedade foi deixada para a Marquise de Castel-Rodrigo, que se casou com o Príncipe Pío de Sabóia, e desde então o espaço ao sul da propriedade foi popularmente chamado de Montanha do Príncipe Pío.

Em 1808, durante a Guerra da Independência contra os franceses, na noite de 2 de maio, quarenta e quatro madrilenos foram assassinados neste lugar pelas tropas napoleônicas. No século XIX, a Estação do Norte foi construída ao pé da Montanha, e em sua parte superior, o Quartel das Montanhas, que foi destruído no início da Guerra Civil. O lugar permaneceu em ruínas por décadas, mas em 1970, o terreno foi cedido à Câmara Municipal de Madrid para criar jardins e reconstruir em sua parte central o Templo de Debod.

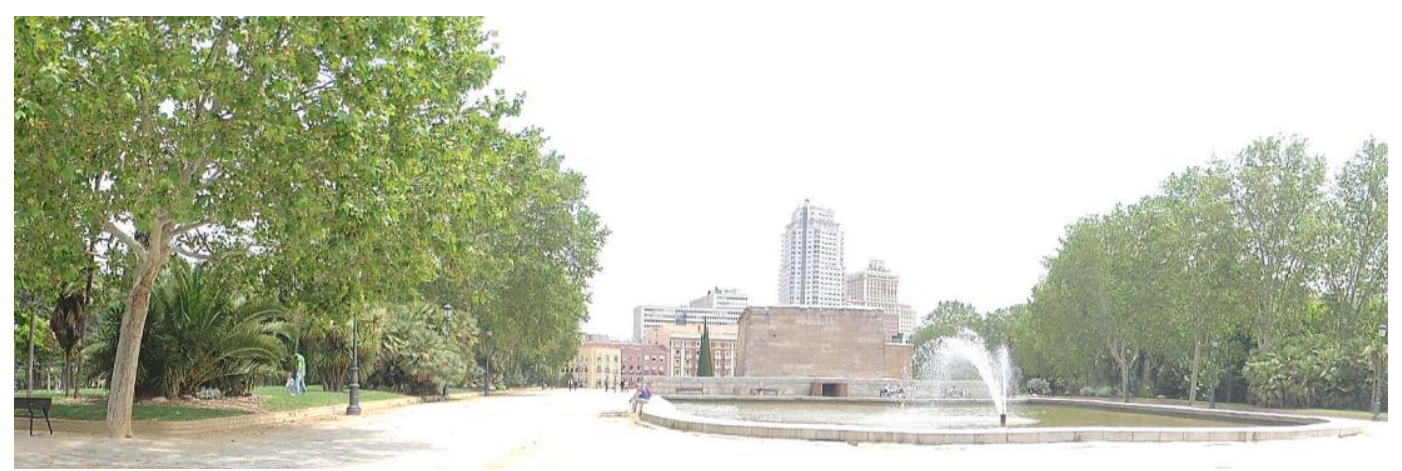

Figura 44 - Vista do Mirante para o Templo de Debod. Fonte: Arquivo Pessoal

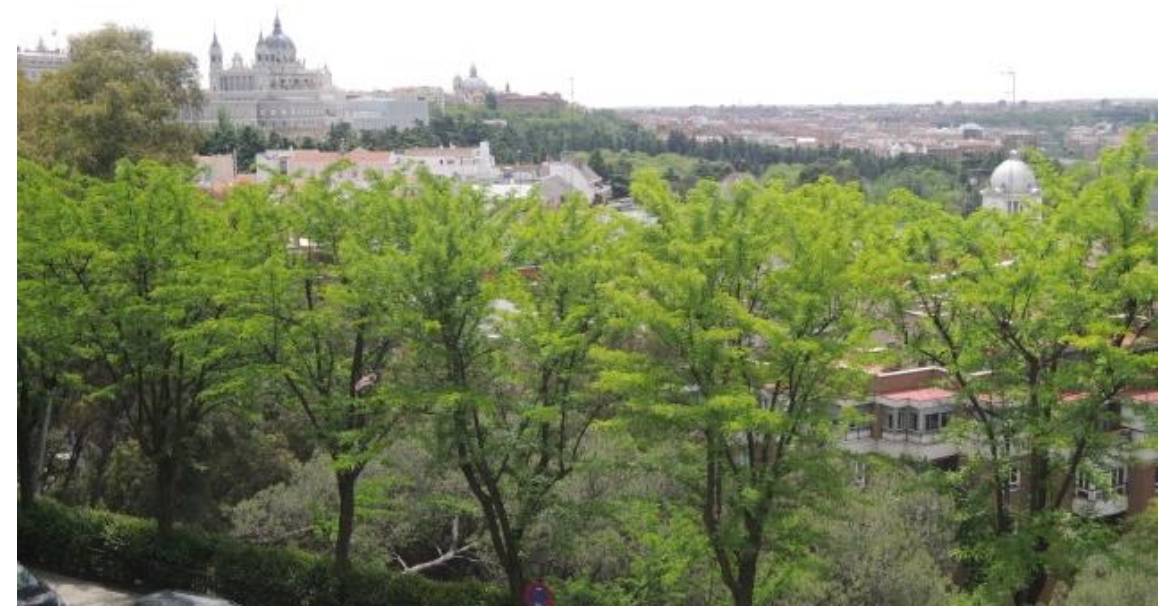

Figura 45 - Vista do Mirante para a cidade. Fonte: Arquivo Pessoal 


\section{Fonte de Juan de Villanueva}

A fonte se encontra no Passeio de Camoens e foi construída para comemorar o centenário da morte de Juan Villanueva. O projeto ganhador do concurso público foi de Victor D'ory e Manuel Ambros, sendo esculpida por Santiago Costa. Sua inauguração, em 1952, foi na Glorieta (carrossel) de São Vicente, onde permaneceu até 1995, depois foi transferida para o local atual, porém em sua instalação parte do monumento foi perdida. A fonte tem um pilão onde se encontra três esculturas que representam três temas de Madrid: Madrid de São Isidro, Madrid Artesão e Madrid Capital. Cada uma dessas esculturas está localizada em parques distintos. A escultura que se encontra no Parque del Oeste foi construída externamente em granito e internamente em concreto, imitando os estilos arquitetônicos de Villanueva. Nela se utilizou ornamentos dóricos, jônicos, coríntios. Sua cascata tem 22 metros de queda, com uma estrutura de distribuição de água (Figura 46).

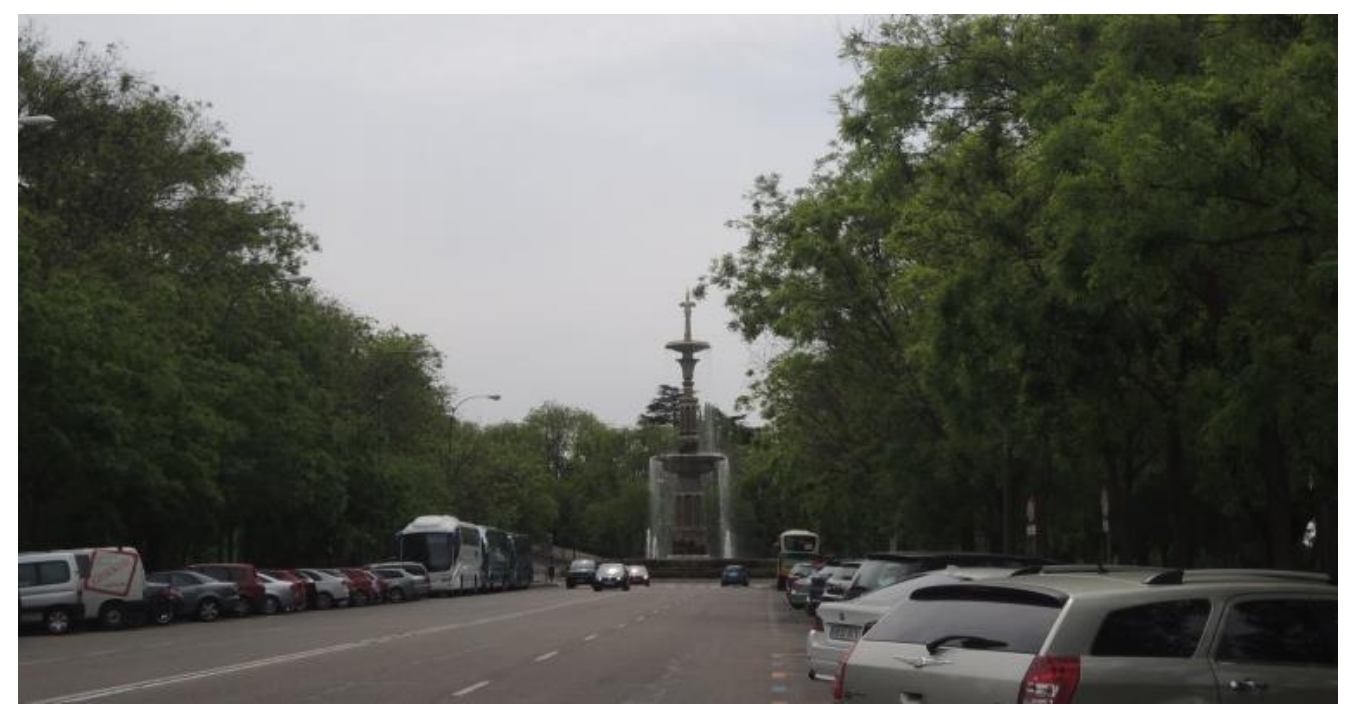

Figura 46 - Fonte de Juan de Villanueva. Fonte: Arquivo Pessoal.

\section{Estátua a Eduardo Rosales}

Eduardo Rosales Gallinas (1836-1873) nasceu em Madrid, filho de um oficial modesto. Estudante de Federico Madrazo. A falta de meios econômicos para começar sua carreira não foi um obstáculo para que viajasse a Roma em busca de melhorar sua formação artística. Lá ele se juntou ao grupo de pintores espanhóis, incluindo Mariano Fortuny, foi formando parte da estética purista. Embora em seus 
últimos anos adotasse o impressionismo, encontrou o seu próprio caminho no realismo, período no qual se encaixa um dos seus quadros mais famosos e que the rendeu a última homenagem. A tela intitulada Isabel la Católica Ditando Testamento, que está atualmente exposta no Museo del Prado e pelo qual recebeu a medalha de ouro da Exposição Universal de Paris em 1867. Em 1869 retorna definitivamente para Madrid, onde morre quatro anos mais tarde (Figura 47).

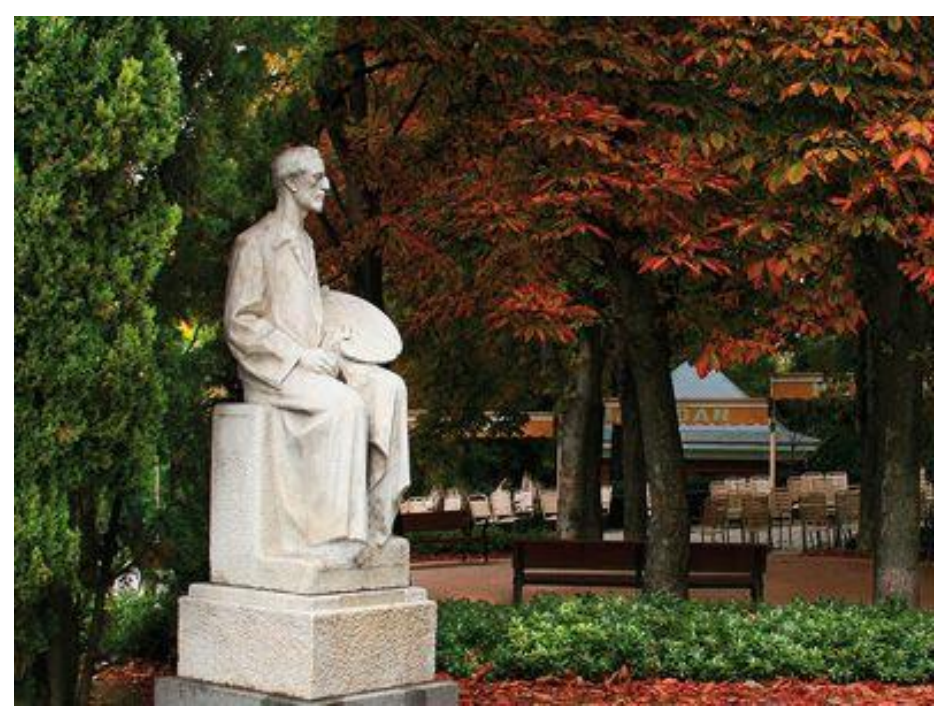

Figura 47 - Estátua Eduardo Rosales. Fonte: https://goo.gl/HYtoit, acesso em 21 de agosto de 2017.

\section{Monumento a Cervantes}

$\mathrm{Na}$ data de comemoração do centenário da morte de Miguel de Cervantes (1616) o Ministério da Instrução Pública e Belas Artes convocou um concurso para construir um memorial a Miguel de Cervantes. Os vencedores escolhidos entre os projetos foram o arquiteto Rafael Martínez Zapatero e o escultor Lorenzo Coullaut Valera. A obra do memorial só começou em 1925, com a colaboração do arquiteto Pedro Muguruza, que o modificou diminuindo algumas ornamentações.

O monumento, com altura de cerca de trinta e cinco metros, é construído em torno de um obelisco moldado e marcado nas suas esquinas por pilares. A base está dividida em duas partes, a primeira é uma base de trinta e sete centímetros onde a segunda sobe até atingir uma altura de mais de dois metros, e com medidas de vinte por vinte metros serve como apoio para todas as estruturas, incluindo a fonte e as estátuas (Figura 48). 
A estátua voltada para sudoeste do monumento representa Cervantes sentado sob um pedestal com estátuas de Don Quixote e Sancho Pança montando, respectivamente, sobre Rocinante e seu jumento usado na base do monumento. Do lado esquerdo tem-se a representação da Dulcinéia del Toboso, e ao lado direito, a imagem de Aldonza Lorenzo. As estátuas têm aproximadamente três metros e foram esculpidas em pedra por Federico Collaut-Valera passando a formar parte do conjunto entre os anos de 1956 e 1957.

O lado oposto é composto por uma fonte construída em mármore, por onde a água cai em um granito semicircular, e por duas estátuas que representam o misticismo e o valor militar simbolizado, por um jovem olhando para o céu e um forte guerreiro armado.

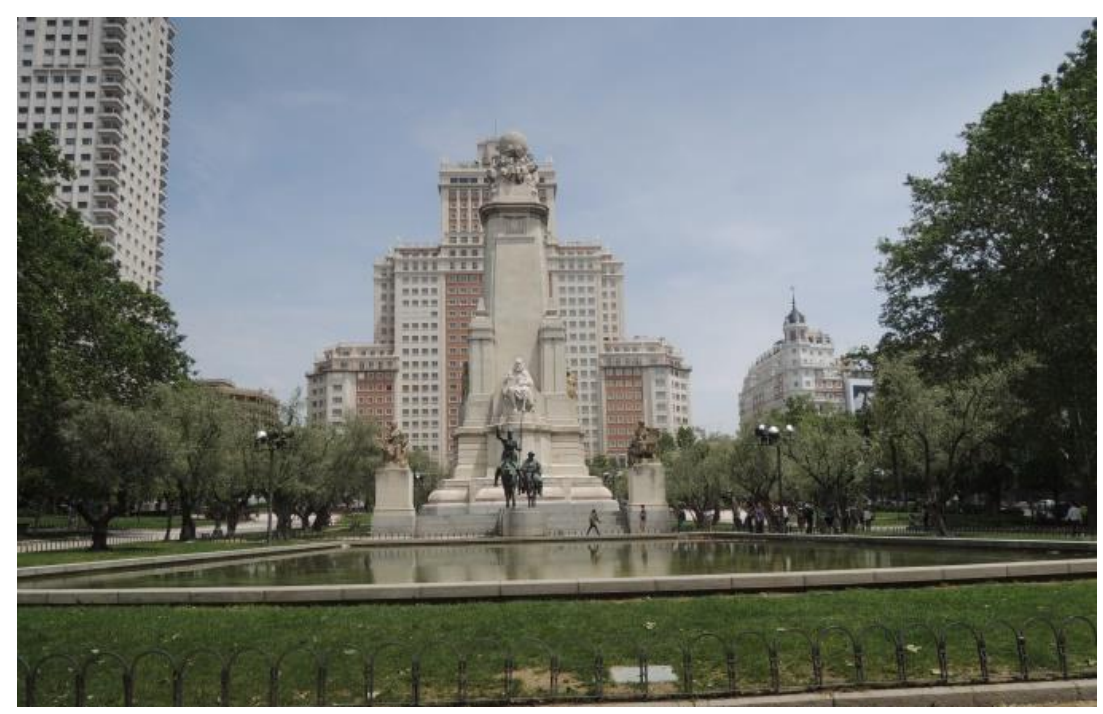

Figura 48 - Monumento a Cervantes._Fonte: Arquivo Pessoal

\section{Observatório de aves}

Desde 1992, o observatório de aves funciona como um centro de estudo onde muitas oficinas e atividades de observação de pássaros são realizadas para descobrir mais sobre seus costumes e vida no parque (Figura 49). Perto dos bunkers, por meio de um caminho botânico de $3 \mathrm{~km}$, existem casas de madeiras penduradas em árvores próximas sendo utilizadas como ninhos artificiais, (Figura 50) que em conjunto com o observatório formam o percurso realizado por eventos como a Gymkhana de las aves (a gincana das aves), que utiliza das épocas de 
migração das aves para a realização do evento, que em conjunto com o Conselho Municipal de Madri e SEO / BirdLife ajudam a atrair os cidadãos de Madrid para o melhor entendimento da proteção e conservação das aves.

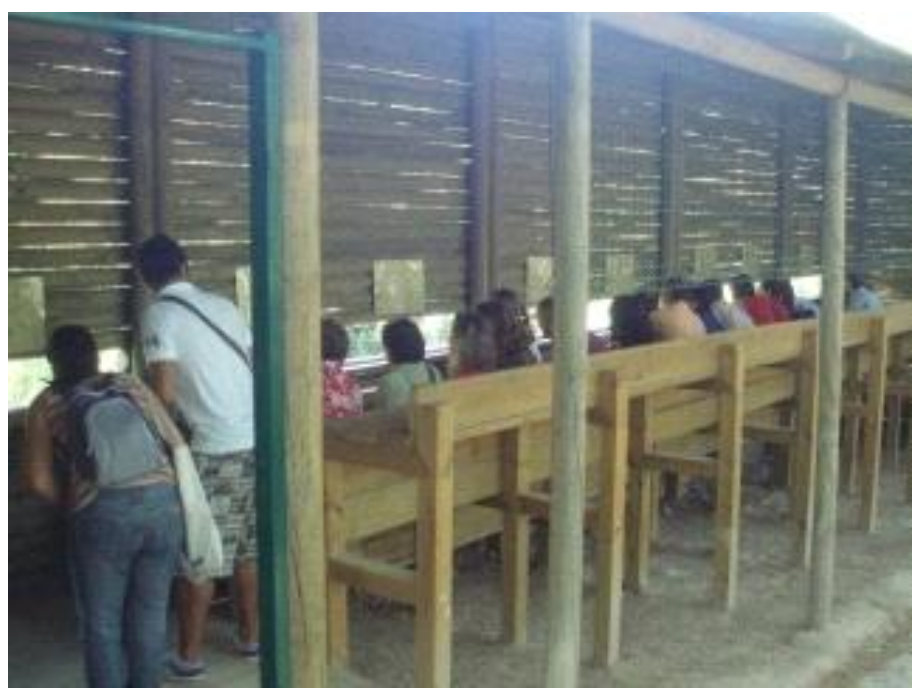

Figura 49 - Observatório de pássaros

Fonte: https://goo.gl/iSW5db, acesso em 21 de agosto de 2017.

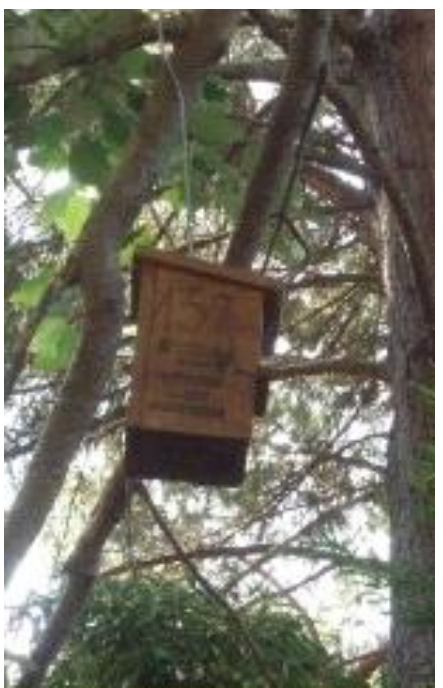

Figura 50 - Ninho artificial.

Fonte: https://goo.gl/iSW5db, acesso em 21 agosto de 2017.

\subsection{Manutenção}

A maior parte dos trabalhos de conservação do Parque del Oeste é feita pela mesma empresa que a do Parque El Retiro, além desses dois parques, essa empresa cuida dos demais parques históricos de Madrid. Devido a sua extensão, as atividades de jardinagem e manutenção são compartilhadas com trabalhadores municipais. O parque conta com auxílio de agrônomos, técnicos agrícolas e florestais, técnicos em obras públicas, engenheiros civis, especialistas em jardinagem e paisagismo.

Em virtude de ser um jardim e possuir um tipo de vegetação que exige maior cuidado, a conservação da Rosaleda é feita pela Dirección General de Gestión del Agua y Zonas Verdes e pela Área de Gobierno de Medio, pois de todos os lugares do parque, este é o único que tem horário de funcionamento próprio. A gestão do parque é baseada em princípios de qualidade, meio ambiente e sustentabilidade, como o uso de máquinas e veículos elétricos para minimizar as emissões de $\mathrm{CO} 2 \mathrm{e}$ ruído, o uso eficiente da água por sistema de irrigação automatizada, além do monitoramento das árvores e da reutilização de compostos orgânicos (adubo) em outros parques de Madrid. 


\section{PARQUE DALIEDA DE SAN FRANCISCO}

\subsection{História}

O Parque Dalieda de San Francisco (Figura 51) está localizado no local do antigo convento de São Francisco, demolido em meados do século XX. Foi inaugurado pelo prefeito de Madrid, Alberto Ruiz Gallardón, em sete de maio de 2007. Há uma lenda de que neste lugar São Francisco de Assis parou sua peregrinação para cristianizar parte da Espanha e promoveu a construção de uma ermida por volta de 1215. A lenda afirma que o lugar é especial pela presença e bênção de uma das figuras históricas do catolicismo.

A área em que este parque está localizado é conhecida como Las Vistillas, o motivo dessa denominação é que está na área mais alta de Madrid de los Austrias, e as vistas são privilegiadas para o sudoeste da cidade, situado próximo ao Palácio Real e a Catedral da Almudena, um complexo muito significativo em Madrid. A ideia do o parque de $4.400 \mathrm{~m}^{2}$ foi dedicar tematicamente ao cultivo de dálias.

O parque consiste em três zonas: os jardins, o mirante e os acessos ao parque da Cornisa. A floração de dália acontece durante os meses de maio até outubro, no restante dos meses as flores caem, mantendo suas raízes que nascem na primavera seguinte, de modo que os canteiros perdem as cores brilhantes da flor, o verde de suas hastes e o parque assume uma cor terrosa.

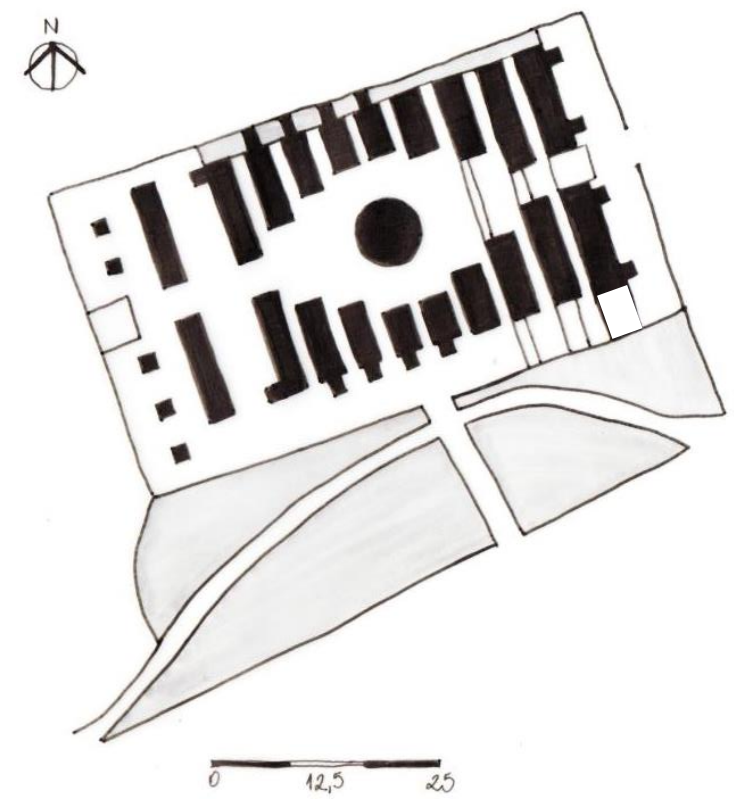

Figura 51 - Mapa do Parque Dalieda de San Francisco. Fonte: Arquivo Pessoal. 


\subsection{Usos}

\section{Jardim de Dálias}

Localizado em cima de um pequeno platô, faz fronteira com a Igreja de São Francisco. O parque possui um jardim temático dedicado ao cultivo de Dálias em uma superfície de $4.242 \mathrm{~m}^{2}$. Consiste em uma série de canteiros de flores localizados em diferentes alturas contendo mais de 50 variedades de dálias. Os espaços entre os canteiros de flores formam alguns corredores para caminhar e contemplar as flores (Figuras 52 e 53). Está aberto todo o ano, mas é mais florido de maio a setembro.

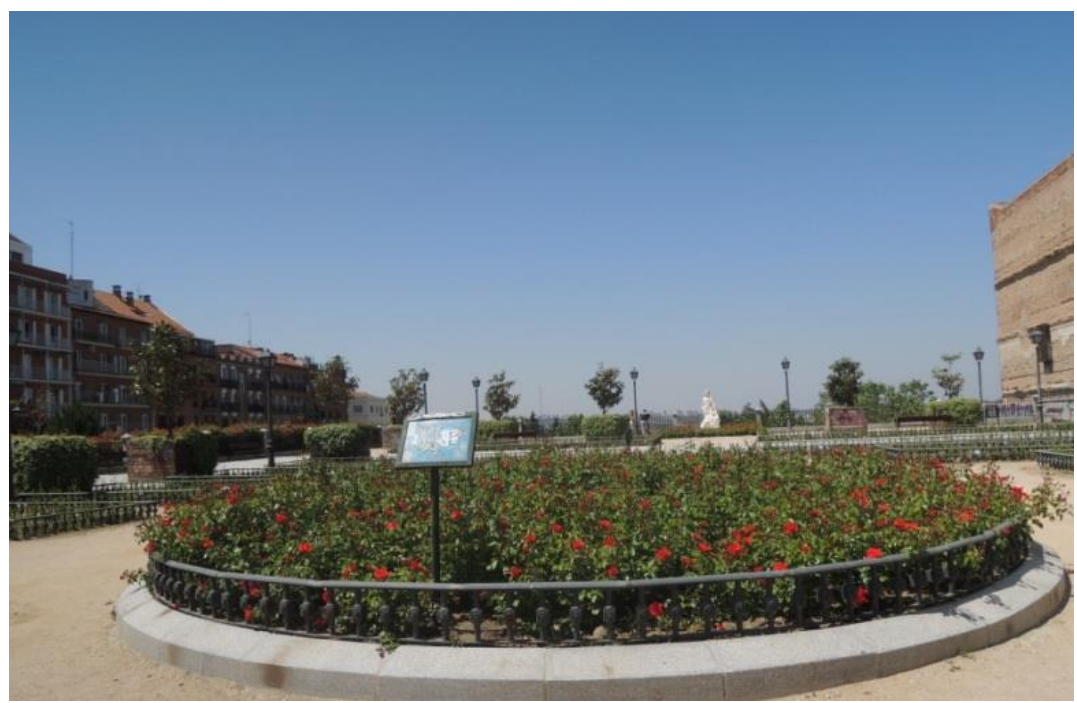

Figura 52 - Canteiro de Dálias. Fonte: Arquivo Pessoal.

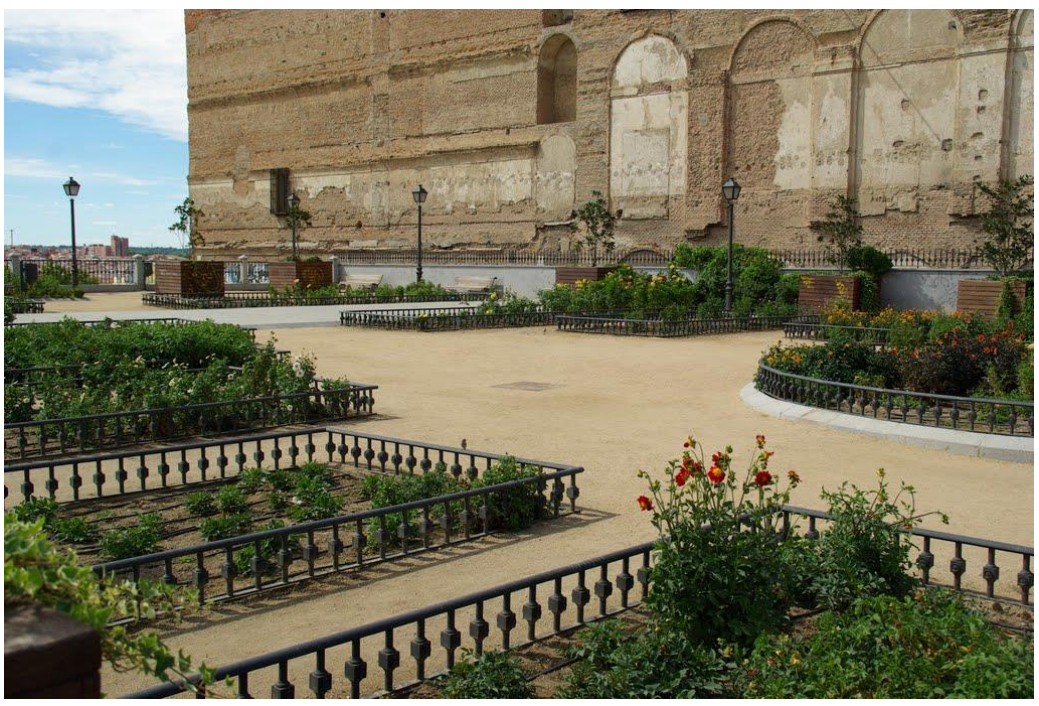

Figura 53 - Espaço verde temático. Fonte: https://goo.gl/xVNZAz. Acesso em 23 de outubro de 2017. 


\section{Mirante}

$\mathrm{Na}$ parte posterior do parque, há um mirante para o sudoeste da cidade, muito utilizado pelas pessoas para apreciar o pôr do sol. Ao lado do mirante está a escultura El sueño de San Isidro, de Santiago Costa, que representa o santo reclinado e um anjo que coloca uma mão em sua cabeça para fazê-lo dormir (Figura 54). Também é possível ver a Basílica de São Francisco (Figura 55) e o parque Cornisa, situados ao lado dos canteiros de dálias.

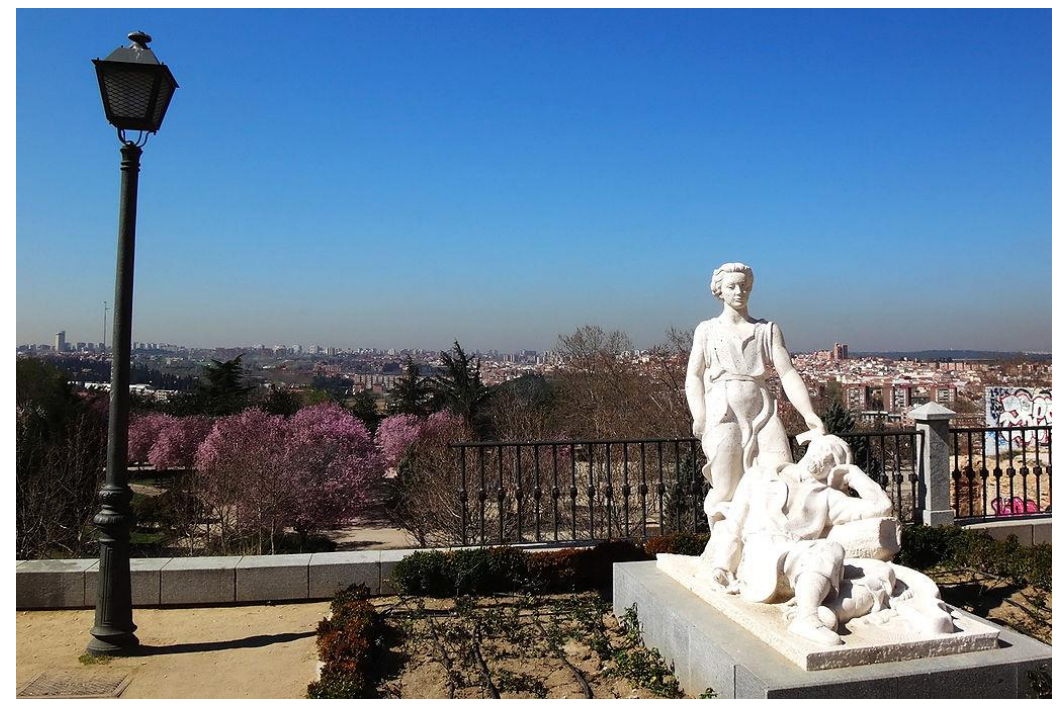

Figura 54 - Escultura El sueño de San Isidro. Fonte: https://goo.gl/wEKX6P. Acesso em 14 de fevereiro de 2018.

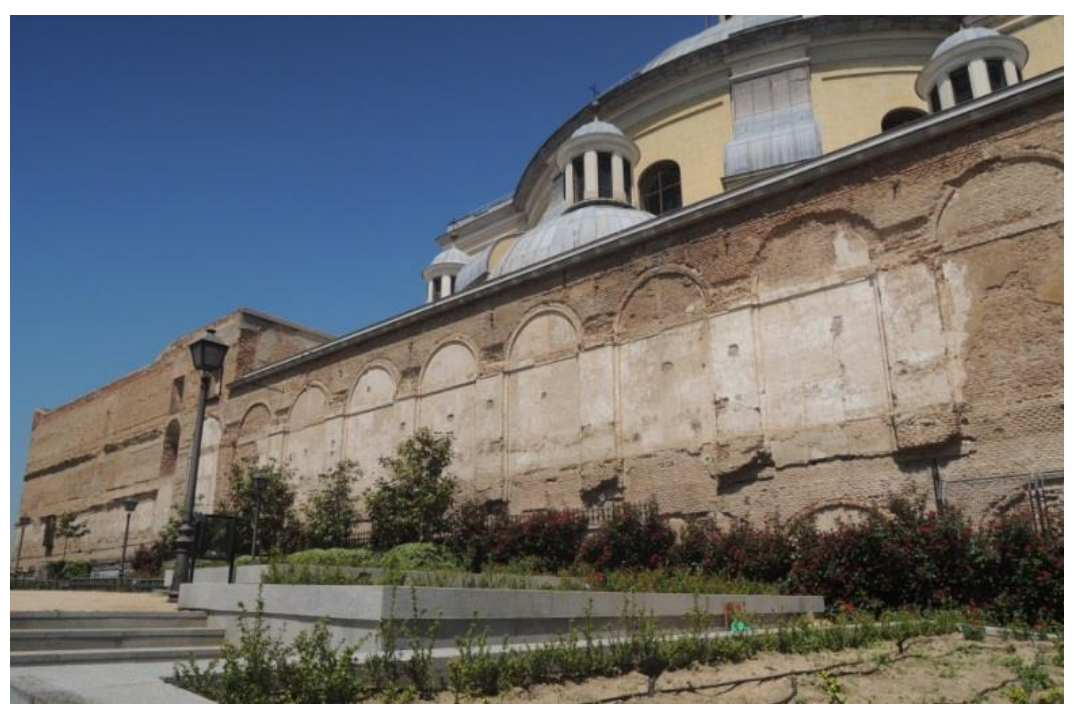

Figura 55 - Canteiro de Dálias com vista para a Igreja de São Francisco. Fonte: Arquivo Pessoal. 


\subsection{Manutenção}

A manutenção e conservação do parque é de responsabilidade da Dirección General de Gestión del Agua y Zonas Verdes e da Área de Gobierno de Medio Ambiente y Movilidad.

A Dirección General de Gestión del Agua y Zonas Verdes tem como função e habilidade a promoção da eficiência da água, disponibilidade e sustentabilidade dos recursos hídricos, utilização de recursos hídricos alternativos, conservação e manutenção da infraestrutura de água. Em âmbito mais específico, o órgão tem a responsabilidade de proteger, conservar e restaurar as áreas verdes e áreas ajardinadas, além de realizar o planejamento, coordenação e supervisão de atividades municipais no campo do parque. (Figura 56).

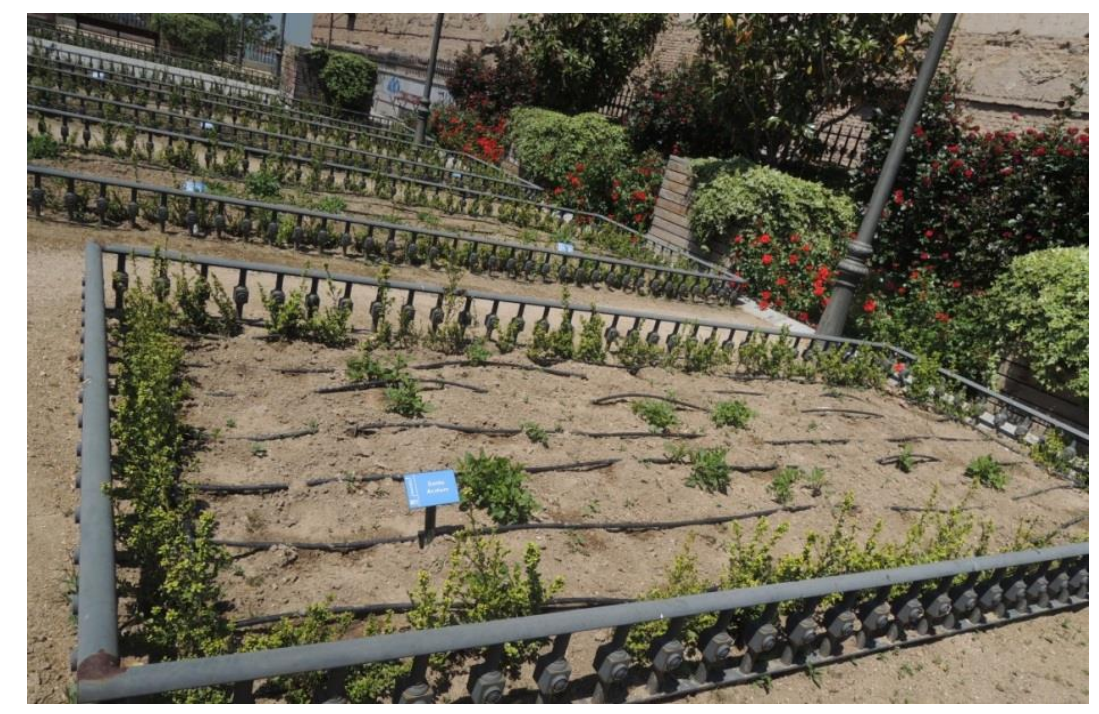

Figura 56 - Manutenção do canteiro de Dálias. Fonte: Arquivo Pessoal.

\section{RESULTADOS E DISCUSSÃO}

Foram analisados os mapas dos três parques urbanos de acordo com o seu uso. Segundo Falcón (2007), as pessoas permanecem nos parques por diversas razões, sendo que as principais são: lúdicas e recreativas, culturais, esportivas, contemplativas ou atividades participativas. 


\begin{tabular}{|c|c|c|c|c|c|}
\hline \multicolumn{6}{|c|}{ Parque El Retiro } \\
\hline Usos & Lúdicas e Recreativas & Culturais & Esportivas & Contemplativas & Atividades Participativas \\
\hline 1 & Estanque Del Retiro & Palácio de Cristal & Quadra Poliesportiva & Monumento de Afonso XII & Feira do Livro \\
\hline 2 & & Palácio de Velazquez & & El Paseo de Coches & \\
\hline 3 & & Biblioteca Pública & & Fonte Egipcia & \\
\hline 4 & & & & Puerta de la Independencia & \\
\hline 5 & & & & Fuente de la Independencia & \\
\hline 6 & & & & El Ángel Caído & \\
\hline 7 & & & & La Rosaleda & \\
\hline
\end{tabular}

Tabela 1 - Usos do Parque El Retiro.

Fonte: Arquivo Pessoal.

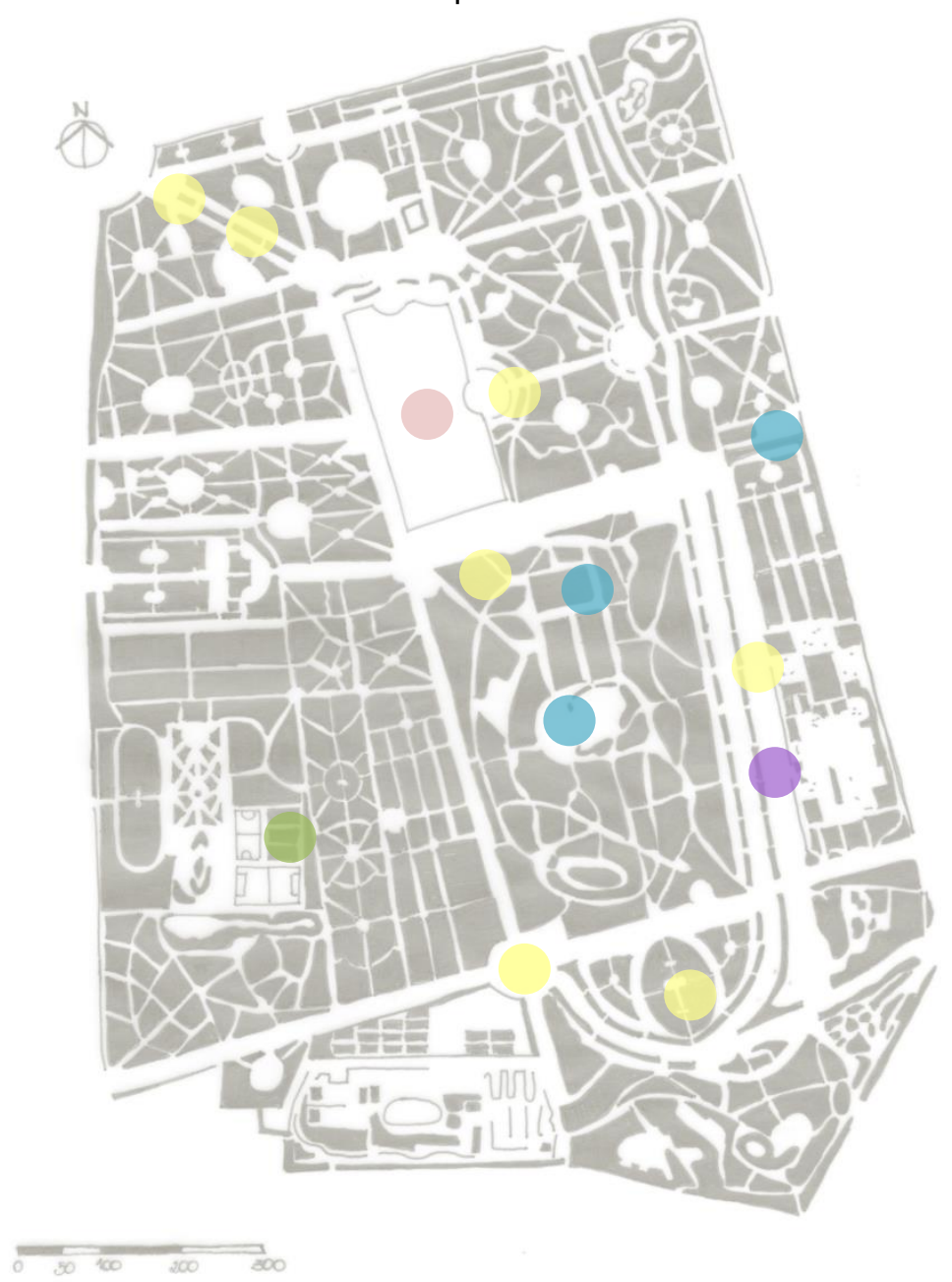

Figura 57 - Mapa do Parque El Retiro com os usos em destaque.

Fonte: Arquivo Pessoal.

No parque El Retiro (Figura 57, Tabela 1) é possível observar a existência dos cinco tipos de uso, o que contribui para a diversidade do público no local, pois terão alternativas diferentes e atividades que poderão realizar nesse parque. Por ser considerado um parque histórico, possui diversos monumentos que contam a história do parque. As atividades participativas são aquelas que o público tem um 
envolvimento maior com o evento realizado. As esportivas estão concentradas nas quadras poliesportivas, embora essa atividade seja desempenhada ao longo de toda a extensão do parque devido a caminhadas praticadas pelos moradores. Os palácios que atualmente funcionam como museu, concentram a maior parte dos eventos culturais, tanto pelas exposições ao longo do ano, como pela arquitetura desses edifícios. Já as atividades lúdicas e recreativas atraem pessoas de todas as gerações e assim como as atividades participativas, entretém as pessoas por mais tempo, aumentando o tempo de permanência no parque.

No parque del Oeste (Figura 58, Tabela 2), assim como no El Retiro, possui as 5 modalidades de uso, sendo que as contemplativas estão dispostas em toda a extensão do parque. Em certos locais, como na Rosaleda, possui dois tipos de uso, embora predominantemente contemplativa, há um uso participativo da população em eventuais concursos de rosas. Nesse parque especificamente há um público diferenciado: as escolas que levam seus alunos para visitar o observatório de aves e participar de gincanas que envolvem as crianças com o aprendizado sobre a natureza. Esse parque é menos visitado pelos turistas, ao se comparar com o El Retiro, mas isso não indica que os elementos contemplativos, as atividades culturais, bem como seus equipamentos esportivos não sejam procurados nesse local.

Já o parque Dalieda de San Francisco (Figura 59, Tabela 3) possui um único tipo de uso: o contemplativo. Essa característica faz com que este parque seja bastante diferente dos parques citados anteriormente, pois atrai basicamente um tipo de público, turistas e moradores interessados por flores. Ao considerar que esse tipo de vegetação floresce na primavera, é exatamente nesse período que a visitação desse espaço é mais decorrente. Devido também a sua extensão e sua inexistência da diversidade de usos, as pessoas tendem a permanecer menos tempo nesse parque, ao comparar com os demais parques estudados (Figura 60).

\begin{tabular}{|c|c|c|c|c|c|}
\hline \multicolumn{2}{|c|}{ Parque del Oeste } & Esportivas & Contemplativas & Atividades Participativas \\
\hline Usos & Lúdicas e Recreativas & Culturais & La Rosaleda & Observatório de aves \\
\hline 1 & Teleférico & Templo de Debod & Quadra Poliesportiva & Monumento a Goya & \\
\hline 2 & & Escola de Cerâmica & & Monumento Sor Juana Inés & \\
\hline 3 & & & & Montanha de Príncipe Pío & \\
\hline 4 & & & & Estátua a Eduardo Rosales & \\
\hline 5 & & & & Monumento a Cervantes & \\
\hline 6 & & & & & \\
\hline
\end{tabular}

Tabela 2 - Usos do Parque del Oeste. Fonte: Arquivo Pessoal. 


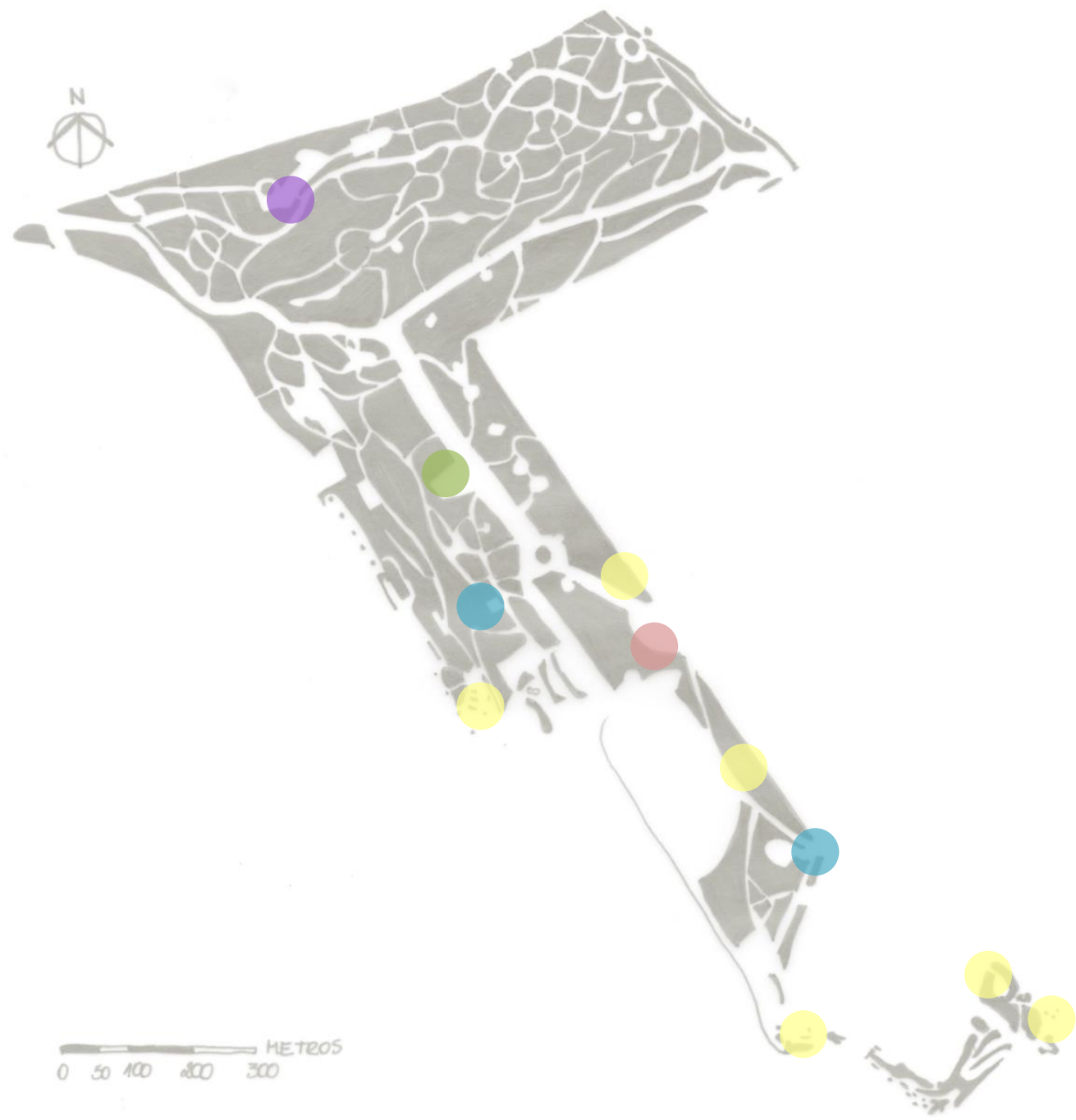

Figura 58 - Mapa do Parque del Oeste com os usos em destaque.

Fonte: Arquivo Pessoal.

\begin{tabular}{|c|c|c|c|c|c|}
\hline \multicolumn{2}{|c|}{ Parque Dalieda de San Francisco } \\
\hline Usos & Lúdicas e Recreativas & Culturais & Esportivas & Contemplativas & Atividades Participativas \\
\hline 1 & & & & Canteiros de dálias & \\
\hline 2 & & & & Mirante & \\
\hline
\end{tabular}

Tabela 3 - Usos do Parque Dalieda de San Francisco.

Fonte: Arquivo Pessoal. 


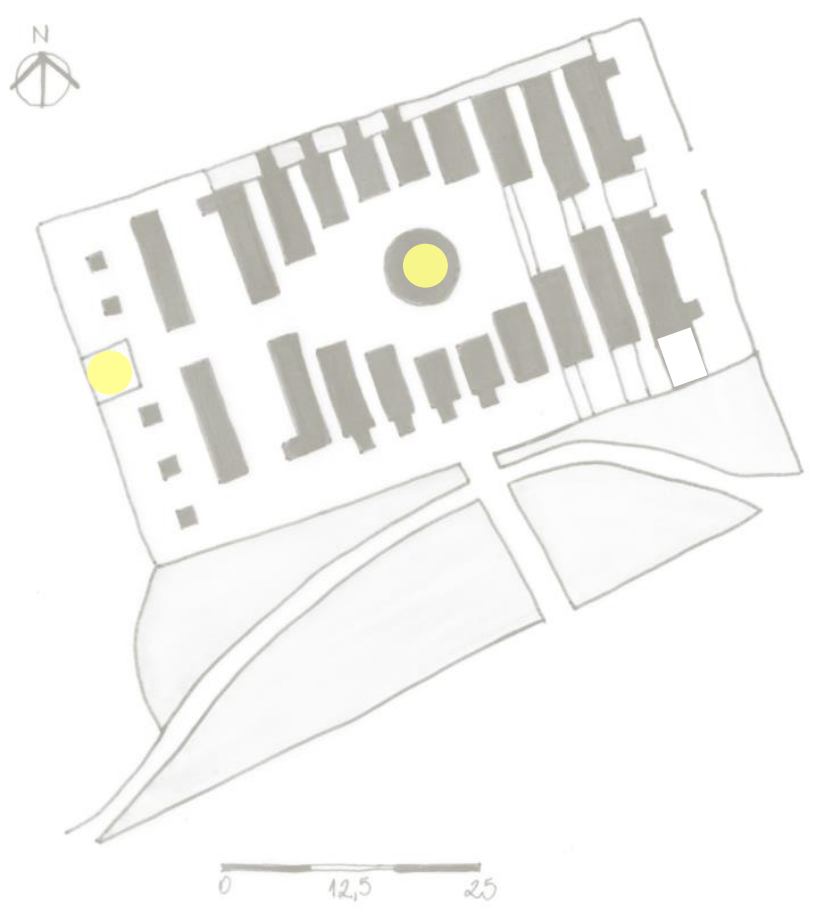

Figura 59 - Mapa do Parque Dalieda de San Francisco com os usos em destaque. Fonte: Arquivo Pessoal.

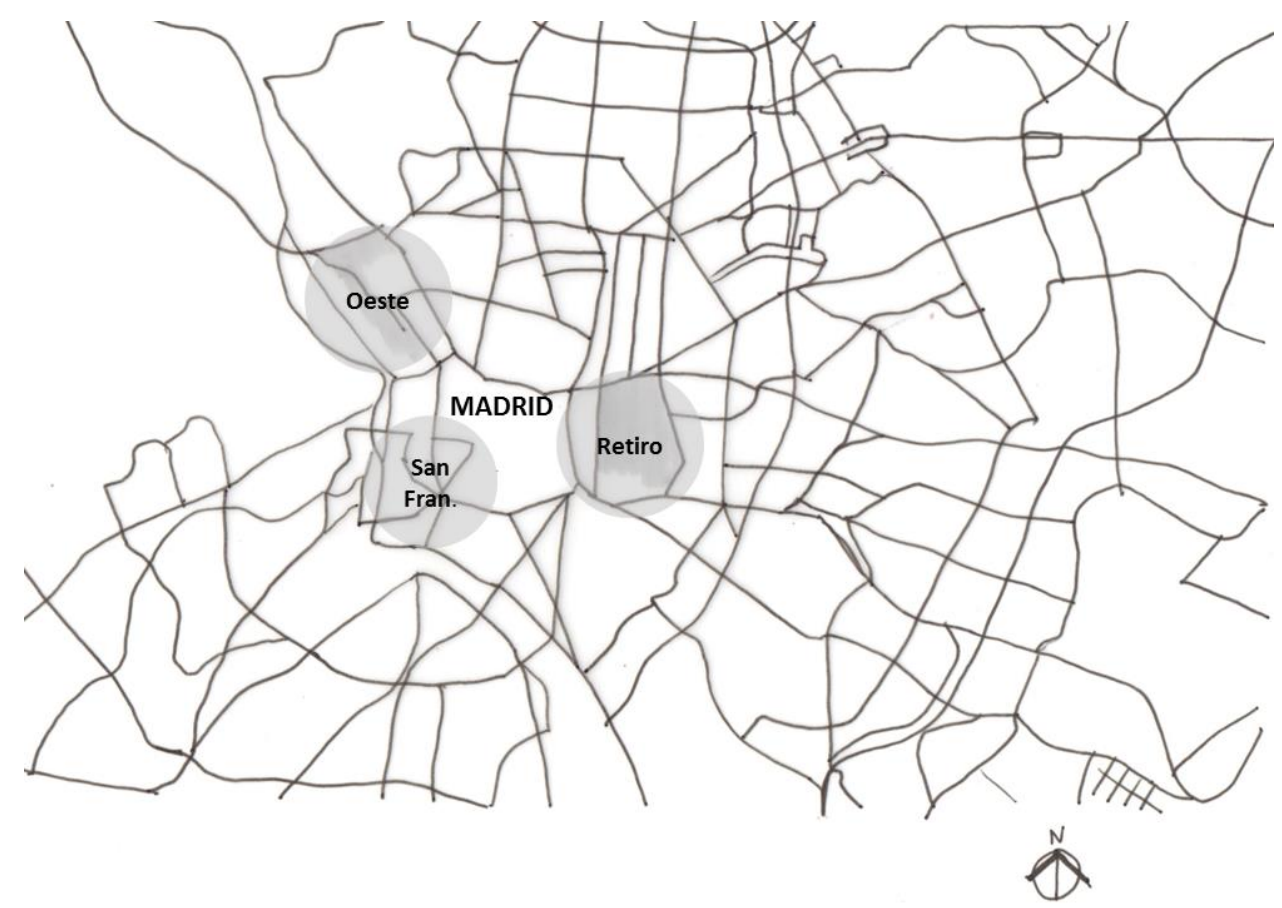

Figura 60 - Mapa de Madrid com a locação dos três parques.

Fonte: Arquivo Pessoal. 


\section{CONSIDERAÇÕES FINAIS}

Com esse trabalho, foi possível estudar os usos dos parques urbanos e sua manutenção na cidade de Madrid. A análise dos projetos possibilitou a categorização dos usos e suas combinações, assim como a compressão de técnicas de conservação e suas tecnologias. Foi alertado, sobretudo, a importância do uso de espécies nativas do local e da coleta e reaproveitamento de água nos parques.

Por meio dos estudos de caso, foi possível exemplificar em nível de projeto a estrutura de um parque urbano e mostrar que é possível projetar parques de modo com que não consuma muita água e que não sobrecarregue o governo economicamente e que, acima de tudo beneficie a população. Vale ressaltar que, qualidade de vida está diretamente ligada às questões ambientais e sociais do indivíduo, portando é preciso da conscientização tanto de profissionais da área ao projetar um parque sustentável, quanto da população ao procurar zelar o espaço utilizado. 


\section{REFERÊNCIAS BIBLIOGRÁFICAS}

CZERNIAK, Julia e HARGREAVES, George. Large Parks. Princeton Architectural Press, 2007.

FALCÓN, Antoni. Espacios Verdes para uma ciudad sostenible. 1 ed. Barcelona: Editorial Gustavo Gili, 2007.

JACOBS, Jane. Morte e vida de grandes cidades. 3a ed. São Paulo: Editora WMF Martins Fontes, 2011.

MARTIN, Luis. Arboles del Retiro: 2 ed. Madrid: Ayuntamiento de Madrid, 1990.

\section{SITES}

http://www.accionaservice.com/es/areasdeactividad/urbanosmedioambiente/proyecto s/parques-historicos-madrid/. Acesso em 24 de agosto de 2018.

http://elretiroyyo.com/estanque/estanque.html. Acesso em 24 de agosto de 2018.

http://www.secretosdemadrid.es/la-estatua-del-angel-caido/. Acesso em 24 de agosto de 2018.

http://ferialibromadrid.com/. Acesso em 24 de jul. de 2017.

http://www.miradormadrid.com/rosaleda-del-parque-del-oeste. Acesso em 17 de ago. 2017.

https://es.wikipedia.org/wiki/Templo_de_Debod. Acesso em 16 de ago. de 2017.

http://www.viendomadrid.com/2011/01/monumento-sor-juana-ines-de-la-

cruz.html\#axzz4pSEzxV45. Acesso em 15 de ago. de 2017.

http://www.miradormadrid.com/montana-del-principe-pio/. Acesso em 18 de ago. de 2017.

http://www.miradormadrid.com/dalieda-de-san-francisco/. Acesso em 16 de set. de 2017. 